\title{
MODELLING THE LONG-RUN ECONOMIC IMPACT OF LEAVING THE EUROPEAN UNION
}

Monique Ebell, NIESR and CfM

Ian Hurst, NIESR

James Warren, NIESR

NIESR Discussion Paper No. 462

Date: 20 June 2016 


\section{About the National Institute of Economic and Social Research}

The National Institute of Economic and Social Research is Britain's longest established independent research institute, founded in 1938. The vision of our founders was to carry out research to improve understanding of the economic and social forces that affect people's lives, and the ways in which policy can bring about change. Seventy-five years later, this remains central to NIESR's ethos. We continue to apply our expertise in both quantitative and qualitative methods and our understanding of economic and social issues to current debates and to influence policy. The Institute is independent of all party political interests.

National Institute of Economic and Social Research

2 Dean Trench St

London SW1P $3 \mathrm{HE}$

T: +44 (0)20 72227665

E: enquiries@niesr.ac.uk

niesr.ac.uk

Registered charity no. 306083

This paper was first published in June 2016

(C) National Institute of Economic and Social Research 2016 


\title{
Modelling the Long-run Economic Impact of Leaving the European Union
}

\author{
Monique Ebell, NIESR and Centre for Macroeconomics \\ lan Hurst, NIESR \\ James Warren, NIESR
}

\section{Abstract}

We model the long-term implications of leaving the EU for the UK economy using NiGEM, the National Institute's large scale structural global econometric model. We examine a scenario in which the UK has no free trade agreement with the EU, focusing on four key shocks: a permanent reduction in the size of the UK's export market share in EU member countries, an increase in tariffs, a permanent reduction in inward FDI flows and the repatriation of the UK's projected net contributions to the EU budget. We calibrate the size of the shocks on a synthesis of the academic evidence. We explain how each of these four shocks is implemented in NiGEM, as well as examining the key mechanisms by which they are propagated through the model. The export market share channel is the main mechanism by which leaving the EU leads to declines in GDP and consumption relative to the long-run baseline, accounting for a long-run decline in GDP of 2.1\% relative to the baseline value, out of a total projected reduction in GDP relative to the baseline of $2.7 \%$.

\section{Acknowledgements}

We thank Angus Armstrong, Oriol Carreras, Jagjit Chadha, Simon Kirby, Jack Meaning, Rebecca Piggott and Jonathan Portes for helpful comments. Any remaining errors are our own.

\section{Contact details}

Monique Ebell (m.ebell@niesr.ac.uk), National Institute of Economic and Social Research, 2 Dean Trench Street, London SW1P 3HE 


\section{Introduction}

The aim of this paper is to analyse the long-term implications of leaving the EU for the UK economy. A key question concerns the counterfactual: What would the relationship between the UK and the rest of the EU, and the rest of the world, look like after a UK exit from the EU? In this article, we focus on a 'WTO' scenario, in which the UK no longer has a free trade agreement for goods or services with the EU. ${ }^{1}$

We model the impact of leaving the EU on the UK economy using NiGEM, the National Institute Global Econometric Model, a multi- country structural Keynesian style general equilibrium model. NiGEM's global nature and explicit trade linkages make it particularly well-suited to modelling the impact on the UK economy of shifts in trade policy. NiGEM is general equilibrium in nature, so that both prices and quantities adjust over time. Moreover, it incorporates endogenous monetary and fiscal policy responses, which are clearly important when dealing with the kinds of adjustments that leaving the EU might bring. It was also used in unconnected studies by the OECD and HMT for their analysis of the same question. We provide a more detailed overview of NiGEM and its properties in the technical appendix.

We focus on four of the best understood economic implications of leaving the EU: reductions in trade with EU member countries, a modest increase in tariffs, a reduction in inward FDI flows and the repatriation of the UK's projected net contributions to the EU budget. For each of these four shocks, we present the size of the shocks, how they are implemented, and the key mechanisms by which they are propagated through the model.

The reduction in trade with the EU, modeled as a decline in the UK's export market share in the EU, is by far the most quantitatively important channel by which leaving the EU affects the UK economy. This reduction works like a demand shock to UK exports, and is accompanied by declines in UK export prices and a sharp depreciation in Sterling. ${ }^{2}$ The depreciation in Sterling feeds through into higher import prices, and inflation. The higher import prices and lower export prices lead to a persistent deterioration in the terms of trade. That is, the loss in market access to the EU leads the UK to both trade less, and to benefit less from that trade which remains. As a result, GDP, consumption and real wages all fall compared to the counter factual of remaining in the EU.

The resulting negative demand shock, coupled with the surge in inflation, would also put the Bank of England in a challenging position in the years immediately after a decision to leave the EU. We assume that the Bank would 'look through' the rises in inflation during this transition period, but would tighten policy once it reverts to a Taylor rule (calibrated with parameters from the Bank's Compass model) beginning in the third quarter of 2018. The decline in demand for UK exports is more persistent than the inflationary effect from Sterling's depreciation, so in the longer term we see a modest loosening of monetary policy due to the trade impact of leaving the EU. However, this loosening is unable to fully counteract the long-run declines in economic activity relative to the baseline of remaining in the EU.

The repatriation of EU contributions does have a positive impact on GDP: However, the size of the UK's net contributions to the UK, estimated to be $0.3 \%$ of GDP in the relevant time frame, is simply too small to outweigh the negative impact of reduced trade and FDI, and increased tariffs.

Taking all of the shocks related to leaving the EU together, we find that in the long run, defined as being

\footnotetext{
${ }^{1}$ In the Ebell and Warren (2016),published in the May issue of the National Institute Economic Review, we also present results from scenarios involving continued close trading links with the EU, based on Norways' EEA membership and Switzerland's bilateral agreements.

${ }^{2}$ It is important to emphasize that all declines are relative to the baseline of remaining in the EU. 
15 years after a decision to leave the EU, GDP is projected to be $2.7 \%$ lower than in the baseline forecast in which the UK remains in the EU. Real wages fall somewhat more, by between $4.6 \%$. Consumption is also hit somewhat harder than GDP, falling by $4.0 \%$.

In this article, we focus on the modeling of long-run shocks to the UK economy after leaving the EU in NiGEM, and on the mechanisms by which each of these shocks affects the model economy. NiGEM allows the UK economy to adjust to its new situation in a variety of ways, and some of these adjustments tend to temper the negative impacts of Brexit in the long run. We first briefly present the scenario and its assumptions, before discussing the modeling of the shocks and the economic mechanisms at work in detail. Then, we bring all the shocks together and show the relative contributions of each shock to the final impacts on GDP and other key macroeconomic variables. Next, we examine the sensitivity of our analysis to the flexibility of export prices. Finally, we compare our modeling approach and results to the OECD (2016) and HM Treasury (2016), the two other studies which used NiGEM to model the potential impact of leaving the EU on the UK economy in the long-run. We attribute much of the difference in results to the productivity shock included in these two comparator studies. Indeed, introducing a 5\% productivity shock into our WTO scenario brings our results into line with those of the OECD (2016) and HM Treasury (2016). The final section offers some conclusions.

\section{The WTO Scenario}

In this article, we focus on a WTO scenario in which the UK has no free trade agreement with the $\mathrm{EU}^{3}$ In this scenario, we focus on four clear economic implications of leaving the EU: reductions in trade with EU member countries, a modest increase in tariffs, a reduction in inward FDI flows and the repatriation of the UK's projected net contributions to the EU budget. We base the size of each shock based on a synthesis of the academic evidence. ${ }^{4}$

Table 1 summarises the magnitudes of our four shocks. We base the size of the reduction in trade with EU member countries on gravity model estimates of the impact of leaving the EU, treating goods and services separate. We base our estimate of the reduction in goods trade with the EU on the evidence presented in Baier, et. al. (2008), whose estimates imply that leaving the EU would be associated with a decline in EU trade of between $50 \%$ and $56 \%$. We take the midpoint of $53 \%$. We base our estimate of the reduction in services trade with the EU on van der Marel and Shepherd (2013), whose estimates imply that leaving a free trade area would lead to a reduction in services trade of $43 \%$. We take a weighted average of these two figures, taking into account that in 2014 , $72.4 \%$ of trade with the EU was in goods. The resulting decline in total UK trade in goods and services with the EU is $50 \%{ }^{5}$

In addition, if the UK no longer had a free trade agreement with the EU, we would expect tariff barriers to rise on EU trade. The average WTO most-favoured-nation (MFN) import tariff is $9 \%$. We assume that an average tariff of $5 \%$ would be applied to trade in goods and services with the EU.

A large body of empirical evidence links inward foreign direct investment (FDI) flows to openness. We base our estimates of the impact of leaving the EU on inward FDI flows on the estimated relationship between openness (measured as the trade share of GDP) and FDI reported in

\footnotetext{
3 In Ebell and Warren (2016), we also consider scenarios involving continued close trading links with the EU, based on Norway's EEA membership and Switzerland's bilateral agreements.

${ }^{4}$ We present this synthesis of the evidence in more detail in Ebell and Warren (2016).

${ }^{5}$ In Ebell and Warren (2016) we also consider 'pessimistic' scenario that total trade in goods and services with the EU declines by $72 \%$, based on estimates in Egger, et. al. (2011).
} 
Ramasamy and Yeung (2010). Their estimates imply that leaving the EU would reduce inward FDI to the UK by $24 \%$, which corresponds to a reduction in UK private sector investment of $3.5 \% .{ }^{6}$ We note that HM Treasury (2016) arrives at similar magnitudes based on its reading of the evidence from gravity models of FDI flows, as does the synthetic control approach favoured by Bruno, et. al. (2016).

Finally, we base our estimates of the size of repatriated net contributions to the EU on the average of the Office for Budget Responsibility's projections for the UK public sector net contributions between 2017 and 2020, which corresponds to $0.42 \%$ of GDP. ${ }^{7}$ We also add a projection of UK private sector receipts from the EU (mainly research funding) of $0.08 \%$ of GDP, based on their average value between 2009 and 2015 from European Commission accounts. Thus, the projected savings in net private and public sector contributions to the $\mathrm{EU}$ is $0.34 \%$, which we round to $0.3 \%$.

\section{Modelling the economic implications of leaving the EU}

In the simulation, the shocks are applied onto the baseline forecast created from the short-run analysis, described in Carreras, et. al. in this issue. Specifically, with the introduction of each new set of shocks (two trade effects, FDI and changes to the budget) we create a new baseline and revert any model changes from the previous shock back to the standard set of simultaneous equations. This allows us to partial out the impact of each shock separately. We then proceed to adjust the model as required for the next set of shocks, we repeat these steps for each set of shocks. Once all the sets of shocks have been run, we compare the final results to the original forecast baseline (April 2016).

\subsection{Trade shocks}

There is a consensus in the academic literature on empirical gravity models of trade that membership in a free trade area is associated with increased bilateral trade flows between members. ${ }^{8}$ The estimated reductions in trade from leaving a free trade agreement in the papers reviewed in Ebell and Warren (2016) range between $50 \%$ and $72 \%$, as described in the previous section. In this article, we focus on the lower of these two estimates.

A key interlinkage in NiGEM is trade between countries. Each country has aggregate export and import volume equations which take an error correction form and are given by;

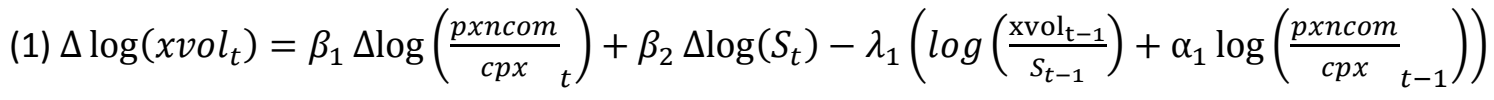

(2) $\Delta \log \left(m v o l_{t}\right)=\beta_{3} \Delta \log \left(t f e_{t}\right)+\beta_{4} \Delta \log \left(r p m_{t}\right)-\lambda_{2}\left(\log \left(m v o l_{t-1}\right)+\alpha_{2} \log \left(r p m_{t-1}\right)+\right.$ $\alpha 3 \log (t)$ fet-1)

Equation (1) states that in the short run export growth $\left(\Delta \log \left(x v o l_{t}\right)\right)$ is determined by the price of non-commodity exports (pxncom) relative to the trade weighted average of competitor's exports prices in \$US (cpx), a measure of relative competitiveness, and the export market size (S). $S_{t}$ is the weighted sum of the relative importance of that country's exports to the import countries. Equation

\footnotetext{
${ }^{6}$ See Ebell and Warren (2016) for a more extensive overview of the empirical FDI literature and a more detailed explanation of Ramasamy and Yeung (2010)'s implications for the UK's inward FDI flows if it were to leave the EU.

${ }^{7}$ Webb and Keep (2016). Also, see Ebell and Warren (2016) for a more extensive treatment of the UK's net contributions to the EU.

${ }^{8}$ We review some of the key papers in this literature in Ebell and Warren (2016). See Head and Mayer (2014) for a more comprehensive overview.
} 
(2) states that in the short run import growth depends on total final expenditure (tfe) and the real import price ( $\mathrm{rpm})$ in domestic currency deflated by the consumption expenditure deflator.

The equations for exports and imports both also include error correction terms. Exports error correct back to equilibrium around relative competitiveness and exports relative to export market size, while imports error correct around import volumes, real import prices and total final expenditure.

Trade is driven by the demand side (imports). This implies that no country can export unless a counterparty is willing to import, and exports merely adjust to ensure global consistency. As a result it is unadvisable to shock the export equation of the affected country directly. One possible way to achieve a reduction in UK exports would be to shock the import demand equations of the UK's trading partners, and then to provide offsetting shocks to the export equations of all other countries such that their exports are unaffected by this fall. As a result the global consistency of the model implies that UK exports to the target countries (the EU) would fall, without affecting exports of other countries to the EU. However, this approach has two drawbacks. Firstly, this implies that a large number of shocks would have to be applied. Secondly and more significantly, the calibration of these shocks is not straightforward. It is not implausible to expect spillovers in trade to close economic neighbours; by applying a large number of shocks, inference of the domestic and international effects become less clear.

Instead, we model loss of access to EU markets through the export market size variable $S_{t}$ in (1). This variable is given as the weighted sum of imports, weighted by exports (to country $n$ ) relative to import market size (of country $\mathrm{n}$ ).

(3) $S_{t}=\sum_{0}^{e u} \phi_{e u} \epsilon_{e u} m^{2} v o l_{t, e u}+\sum_{0}^{r w} \phi_{r w}$ mvol $_{t, r w}$

Where the subscript eu or rw represents a country in the EU or the rest of the world and the term $\epsilon$ is the scaling factor applied to EU weightings only. This scaling factor allows us to mimic the effect of a fall in import demand from EU countries as a result of non-tariff barriers. If $\epsilon_{e u}$ falls to 0.5 this implies a halving of the size of EU import markets for the EU. We assume that the variable transitions to its new post-Brexit level linearly over two years beginning in 2017 Q1, after which it remains at its new equilibrium level to the end of our scenario period. As a result, export volumes $\left(u k x v o l_{t}\right)$ fall, as illustrated in Figure 1. The decline in export demand feeds through into a depreciation in Sterling, as illustrated in Figure 2.

The exchange rate depreciation feeds through into a decline in aggregate export prices, both to the EU $\left(\right.$ pxnceu $\left._{t}\right)$ and to the rest of the world $\left(\right.$ pxncrw $_{t}$ ) (Figure 3), as a depreciation in Sterling makes UK exports cheaper in foreign currency terms:

(4) $\Delta \log \left(\right.$ pxnceu $\left._{t}\right)=\beta_{5} \Delta \log \left(\operatorname{ced}_{t} r x_{t}\right)+\beta_{6} \Delta \log \left(\operatorname{ced}_{t-1} r x_{t-1}\right)-\lambda_{3}\left(\right.$ pxnceu $\left.+\alpha_{4} \mathrm{cpx}\right)$

(5) $\Delta \log \left(\right.$ pxncrw $\left._{t}\right)=\beta_{5} \Delta \log \left(\operatorname{ced}_{t} r x_{t}\right)+\beta_{6} \Delta \log \left(\operatorname{ced}_{t-1} r x_{t-1}\right)-\lambda_{3}\left(\right.$ pxncrw $\left.+\alpha_{4} \mathrm{cpx}\right)$

(6) pxncom $_{t}=\theta$ pxncuk $_{t}+(1-\theta)$ pxncrw $_{t}$

In addition, the depreciation in Sterling makes imports more expensive, leading to an increase in aggregate import prices $\left(\right.$ pmncom $\left._{t}\right)$. The increase in import prices leads to drops in import volumes (Figure 4). 
We chose to offset some of the effect onto export prices through a shock to the price of noncommodity exports. ${ }^{9}$ There are two reasons for this offset. One motivation is the observed behaviour of export prices between 2007 and 2009, when Sterling depreciated by 25 per cent in effective terms. Only around half of this depreciation was passed through to export prices,, suggesting that exporters choosing to widen margins rather than increase market share (Kirby et al,2016). In addition, given the large magnitudes of the depreciation, many export firms might not be able to absorb the corresponding falls in export prices without exit from the market, as firm bankruptcy is not explicitly modelled within NiGEM.

The depreciation in Sterling and the higher import prices also feed through into inflation (Figure 5), which leads to a temporary tightening of monetary policy by the Taylor rule (Figure6). ${ }^{10}$ The declines in GDP and consumption relative to baseline are displayed in Figures 7 and 8 . The declines in export market shares cause GDP to increase slightly, by $0.2 \%$ relative to baseline in 2017 . The reason is that the forward-looking exchange rate depreciates quickly, providing a mild stimulus to the economy, while the export market share declines are only just being phased in. Once the export market share shocks are fully phased in, GDP is lower than its baseline. Aggregate consumption declines more than GDP mainly due to the persistent terms of trade deterioration (Figure 9) caused by rising import and falling export prices.

\subsection{Tariff shock}

We assume that the EU countries impose tariffs on UK exports (and vice-versa), while tariffs with the rest of the world remain the same. To do this we split the UK non-commodity export price equations into EU and rest of the world export prices, equations (4) and (5) respectively. These two series are then weighted by the proportion of exports to the EU and the rest of the world in total trade to create the aggregate series pxncom $_{t}$ (equation 6) which feeds into the export equation (1). As with the other behavioural equations in NiGEM, the export price equation is in error correction form.

We apply a shock which shifts the intercept in equation (4) such that export prices to the EU are increased by 5 per cent on impact in the third quarter of 2018, corresponding with the end of the two-year Article 50 negotiation period. Thereafter, throughout the simulation period, we impose a smaller shock to partially offset the error correction term in (4), $\lambda_{3}$, so that the shock is persistent. We calibrate these offsets so that by the end of our scenario period, the price of non-commodity exports is 2 per cent higher than the baseline value. This can be interpreted either as the UK eventually reaching agreements on lowering tariffs with the EU, or as a shift in the composition of UK exports towards goods or services with relatively lower tariff burdens.

As the tariff is two-way, we also need to apply analogous shocks to the export prices of EU countries to the UK. We do this by splitting the export price equations for EU countries into UK and rest of the world components, and applying the tariff shock described above to EU export prices to the UK.

In order to take into account that for every exporter there is a counterparty importer we also need to adjust the non-commodity import price equations. These are given by equation (7) below, where import prices are given as the trade weighted sum of exporter's non-commodity prices

\footnotetext{
9 We discuss calibrations of this shock and the sensitivity of our results to it in more detail later in the paper. Briefly, we apply an initial shock to the error term, and then for each period afterward we apply a smaller shock which offsets the error correction term calibrated to provide the same profile as price of non-commodity exports without the additional shock.

${ }^{10}$ We assume that monetary policy reacts via a standard Taylor rule, which has been calibrated according to the parameters used in the Bank of England's Compass model.
} 
For each EU country we replace the price of non-commodity exports (pxncom) from the UK with either the left hand side of (4) or (5) depending on whether the country is part of the EU or not. We repeat these steps analogously for the UK's import prices, taking into account the tariff on EU exports to the UK.

While the export market share shock lowered UK export prices while increasing UK import prices. In contrast, the tariff shock increases both UK export and import prices, but the impact is much smaller in magnitude. This is illustrated by the green bars in Figures1 and 10, which show the impact of the $5 \%$ tariff shock on UK export and import prices, respectively. In line with these price movements, the tariff shock causes both UK imports and exports to fall, but again the magnitudes are small compared to the impact of the export market share shock. Also, the rise in import prices is modestly inflationary in the short-run (grey bars in Figure 5), and contributes to a monetary tightening under the Taylor rule, as illustrated by the Figure 6 . This leads, by uncovered interest rate parity, to a small temporary appreciation in Sterling due to the increase in tariffs, peaking at a $0.6 \%$ increase relative to base in 2019 (Figure 2). Again, however, this appreciation is much smaller in magnitude than the depreciation via the export market share channel discussed in the previous sub-section. The impact of the tariff shock on GDP and consumption is given in Figures 7 and 8: Again, the impact of the tariff shock on GDP and aggregate consumption is small compared to the impact of the export market share shock. In addition, the impact of the tariff shock is somewhat greater on consumption than on GDP. The larger impact on consumption is as a result of the rise in import prices, coupled with a rise in the interest rate due to the monetary policy tightening, which causes agents to shift away from consumption and towards savings.

\subsection{Foreign direct investment}

There is a consensus in the academic literature that membership in a free trade agreement leads to increased inward FDI flows. ${ }^{11}$ We base our estimates for the decline in inward FDI flows on Ramasamy and Yeung (2010)'s estimates of the impact of openness on inward FDI flows, together with declines in openness corresponding to the declines in trade flows from the gravity literature. The resulting estimates for the decline in FDI inflows to the UK are quite similar to those reported in HMT (2016): 24 per cent for the WTO scenario, compared to 18- 26 per cent in the Treasury's WTO case, although our estimates were obtained using a different methodology. A reduction in inward FDI of $24 \%$ corresponds to a decline in UK private sector investment (PSI) of $3.5 \%$. ${ }^{12}$ We calibrate a shock such that UK PSI decreases by 3.5\% relative to its non-Brexit baseline by the end of the scenario, coupled with a corresponding permanent negative shock to the balance of payments. These shocks are applied at the end of the assumed two-year Article 50 negotiation period in 2018 Q3.

We approach a decline in FDI flows into the UK as a result of exit from the European Union simply as a fall in investment; this departs from other studies which assume that reductions in FDI are associated with reductions in productivity (see HMT 2016, OECD 2016). The capital accumulation and the corresponding investment flow equations are given as follows,

$$
\left.\Delta \log \left(k_{t}\right)=\beta_{8} \Delta \log \left(k_{t-1}\right)+\beta_{9} \Delta y_{t}+\beta_{10} \Delta y_{t-1}-\lambda_{4}\left(k_{t-1} / y_{\text {cap }}+12\right)+\operatorname{sigma}_{t} * \text { user }_{t}\right)
$$

\footnotetext{
${ }^{11}$ For a review of the academic literature on the impact of free trade agreement membership on inward FDI flows, see Ebell and Warren (2016).

${ }^{12}$ See Ebell and Warren (2016) for details of how we arrive at these figures.
} 
where, user is the user cost of capital ( $u s e r_{t}$ ) is a function of the long real rate, investment premia and the corporate tax rate, $y c a p_{t}$ is the potential output given by the mix of capital, labour, labour augmented technical progress and energy given in the production function. Equation (9) shows that the capital stock adjusts to the new equilibrium path given the ratio between the capital stock in the previous period and expected potential output 3 years in the future. Investment then adjusts so the capital stock moves towards this desired equilibrium value. We apply the shock as a small negative shift to the intercept of the capital accumulation equation (9) in each period for the entire the simulation period. Figure 11 shows the impact of this shock on UK private sector investment, which indeed falls by $3.5 \%$ relative to its baseline remaining in the $\mathrm{EU}$ in the long term.

Alongside the shock to the capital stock, we would also expect there to be an effect on the current account due to the fall in inward flows of FDI. We model this through the balance of payments transfers, which is given by the simple equation,

$$
b p t_{t}=\frac{y_{t} \times p y_{t}}{r x_{t}}
$$

That is, the balance of payments transfers grow in line with nominal GDP priced in dollars. We calibrate the fall as a fall in the percentage of nominal GDP in dollar terms and then apply the shock as an additive (negative) shift in each period.

Figure 11 shows the impact of the shock on private sector investment, while Figure 6 shows that the FDI shock contributes to the monetary policy loosening, as the assumed Taylor rule would be projected to soften the blow on the economy. This loosening leads to a depreciation in Sterling via uncovered interest rate parity, and as a result, the FDI shock leads to a decline in export prices (Figure 3), an increase in import prices (Figure10) and the corresponding increases in exports and declines in imports. The impact of the FDI shock on GDP is small and negative (green bars in Figure 7), but the FDI shock on its own leads to a small increase in consumption, as illustrated in Figure8. This is due to the impact of lower interest rates due to monetary policy loosening, which cause a shift away from savings and towards consumption.

\subsection{Repatriation of net contributions to the EU}

The UK is a net contributor to the EU budget: we contribute a larger amount to the UK budget than we receive back in EU spending. The amounts involved are fairly small, however. Between 2017 and 2020, the UK's contribution to the EU budget, net of both public and private sector receipts from the $\mathrm{EU}$, is projected to average $0.3 \%$ of GDP. ${ }^{13}$ We assume that if the UK left the EU, the government would use the repatriated contributions to increase spending, specifically government consumption, and also make an appropriate adjustment to the balance of payments. We assume that the repatriation of the UK's net contributions to the EU would take effect in the $3^{\text {rd }}$ quarter to 2018, after the end of the two year Article 50 negotiation period. We implement this shock as an improvement of the budget position. We chose this option rather than a reduction in government spending as the latter would imply a negative effect on GDP emanating from multiplier effects. The budget is given by the following identity,

$$
\operatorname{bud}_{t}=\operatorname{tax}_{t}+\operatorname{mtax}_{t}+c t a x_{t}-g c v_{t}-g i v_{t}-\operatorname{tran}_{t}-i p_{t}
$$

${ }^{13}$ These projections are based on OBR and HM Treasury projections, as reported by Webb and Keep (2016), together with EU data on EU spending in the UK. 
The budget is therefore the difference between the incomes generated by tax receipts, comprising direct taxes $\left(\operatorname{tax}_{t}\right)$, corporation taxes $\left(\operatorname{ctax}_{t}\right)$ and miscellaneous taxes $\left(\operatorname{mtax}_{t}\right)$, and the outlays from the nominal values of; government consumption $g c v_{t}$, investment $g i v_{t}$, transfers $\operatorname{tran}_{t}$ and interest payments on government debt $i p_{t}$. The model includes a solvency rule, which we chose to leave on; this solvency rule adjusts the direct tax rate so that incrementally in each period the budget moves back towards its target. More formally the change in the direct tax rate is given by,

$$
\Delta \operatorname{taxr}_{t}=\frac{y_{t} p y_{t} \varphi\left(\frac{\text { budtarget }}{y} t_{t}-\frac{b u d}{y_{t}}\right)}{p i_{t}}
$$

Where, $p y_{t}$ is the GDP deflator and $p i_{t}$ is personal income.

The repatriation of the contribution to the budget implies an improvement in the balance of payments transfers. We apply the shock in a similar manner to that of the FDI shock except that in this case it we would expect an improvement in the balance of payments. We calculate the absolute value of the balance of payments improvement in dollar terms given the percentage of GDP and apply this as an additive shift in each period. Furthermore, we apply the opposite of this BPT shock across the remaining member nations weighted by their relative contributions to the EU budget, to simulate an increase in contributions to keep the EU budgets for the rest of the EU at the same level.

We finally make the assumption that with the extra budgetary space is used by the government for consumption purposes; this equation is given by

$$
\Delta \log \left(g c_{t}\right)=\beta_{12}\left(\log \left(g c_{t-1}\right)-\log \left(y c a p_{t+1}\right)\right)
$$

We apply the shock as a shift to the intercept calibrated such that it represents the increase in real government consumption as a percentage of GDP that would be implied from the improvement in the budget.

The repatriation of EU contributions has a small stimulatory effect. This leads to a very small and temporary increase in GDP of at most $0.15 \%$ compared to the baseline (the blue bars in Figure7). This leads to a modest tightening of monetary policy, and a small appreciation in Sterling. Overall, a repatriation of $0.3 \%$ of GDP in EU contributions is too small to have more than a very marginal impact on macroeconomic variables.

\section{Modelling the total impact of leaving the EU}

We now bring together the four shocks discussed in the previous section, and examine their combined impact on the UK economy after leaving the EU.

Table 2 summarises the main results for key macroeconomic aggregates. We focus on the long-run implications for the UK economy and compare outcomes for our WTO scenario to the baseline of remaining in the $\mathrm{EU}$ in the long-run.

The loss in EU market share would result in long-term declines in total trade of around 21 per cent. The resulting decline in GDP relative to the long-run baseline is projected to be 2.7 per cent. The impact on households is projected to be stronger: real consumer wages are projected to fall by 4.6 per cent, while consumption is projected to drop by 4.0 per cent, both relative to the 2030 baseline.

From Figures 7 and 8 , it is apparent that the export market share channel is the predominant mechanism by which leaving the EU leads to declines in GDP and consumption relative to the longrun baseline. The export market share channel accounts for a decline in GDP of $2.1 \%$ relative to the 
long-run baseline, while FDI accounts for a further $0.3 \%$ decline, and the tariff channel for only a $0.1 \%$ decline in GDP relative to baseline. The positive impact on GDP of repatriating the net contributions to the EU is so small that it rounds to zero. This is due to the relatively small size of the UK's net contributions to the EU compared to GDP.

The larger impact of leaving the EU on consumption than on GDP can also be traced mainly back to the export market shares channel. Via the export market channel (the red bars in Figures 7 and 8), the decline in consumption relative to baseline is $2.8 \%$ rather than $2.1 \%$ for GDP. The persistent deterioration in the terms of trade due to the export market share channel means that imports and hence the consumption basket become more expensive relative to goods produced in the economy. This greater price increase for consumption rather than GDP leads to a greater decline in consumption relative to the decline in GDP. Real consumer wages are also subject to thisterms of trade effect coming in via the export market shares channel.

\section{Senisitivity Analysis}

In the previous section, we showed that most of the impact of leaving the UK on key macroeconomic aggregates such as output, consumption or the exchange rate was due to the shock to export market shares. Export prices are a key variable in the transmission of this shock: The more flexible are export prices, the more that falls in export market share might be 'cushioned' by increases in export demand due to more competitive pricing.

In this section, we examine the sensitivity of our results to the flexibility of export prices. We allow both for more flexible and less flexible export prices, and examine the impact on the magnitudes of the declines in exports and on GDP. . As described in the previous section, we mimic the recent trend in the amount of pass through from the exchange rate to export prices by positively shocking the non-commodity export price equation. We calibrate this so that the growth profile remains broadly the same as a scenario without any supplementary shock, but the impact of our trade shocks lead to a smaller fall in export prices. Our central case assumes that 60 per cent of exchange rate movements are passed through to export prices, while our optimistic and pessimistic cases assume +/- 20 per cent more/less pass through either side of this.

Figure 12 illustrates the reductions in UK export prices in the central case as well as in alternative low and high pass-through (or higher and lower price flexibility) cases. Figure 13 illustrates that less export price flexibility is associated with a greater reduction in exports relative to baseline, as one would expect from first principles. The greater reduction in exports is, in turn, associated with a larger decline in GDP relative to baseline. In the low export price flexibility case, GDP declines by $3.0 \%$ relative to baseline, compared to $2.7 \%$ in the central case and $2.3 \%$ in the high price flexibility case (Figure 14).

\section{Comparisons to other approaches and the impact of productivity shocks}

Table 3 compares our estimated long-run reductions in GDP to those of two other studies which also use NiGEM as the basis for their analyses of the impact of leaving the EU on the UK economy: the analyses published by the OECD (2016) and by HM Treasury (2016). ${ }^{14}$ In our comparisons, we focus

\footnotetext{
${ }^{14}$ In Ebell and Warren (2016), we present results for two WTO scenarios which differ according to 'optimistic' and 'pessimistic' assessments of the impact on export market shares. Here, we focus only on the WTO 'optmistic' case. WTO+ adds a 5\% productivity shock to the WTO 'optmistic' scenario.
} 
on the 'WTO' case in which the UK does not have a free trade agreement with the EU. While all three studies assume similar reductions in trade and FDI, as well as similar reductions in the UK's net contributions to the EU, the range of estimated impacts on GDP relative to the long-run baseline is considerably larger: The OECD projects that GDP would decline by between $2.7 \%$ and $7.7 \%$ relative to baseline in the long-run in its WTO scenarios, while HM Treasury projects declines in GDP of $5.4 \%$ to $9.5 \%$ relative to baseline for its WTO scenarios. We summarise these results by reporting the estimated reduction in GDP for each percentage point reduction in total trade. In the OECD and HM Treasury analyses, GDP is reduced by 0.3 per cent to 0.4 per cent for each 1 per cent reduction in total trade, while in our analysis, GDP is reduced by about 0.1 per cent for each 1 per cent reduction in trade..

What accounts for the lower impact on GDP despite fairly similar reductions in trade and FDI? One key distinguishing feature of our analysis is that our WTO scenario abstracts from any direct impact of openness on productivity, while both the HM Treasury (2016) and OECD (2016) analyses appeal to evidence on the impact of openness on productivity (cf. Melitz and Tefler (2012), Melitz and Redding (2014) and Bloom et al(2014)) as a basis for implementing direct shocks to productivity in NiGEM.

HM Treasury (2016) does not give the size of its productivity shock, but does report that its analysis is based on an elasticity of productivity to trade of between 0.2 and $0.3 .{ }^{15}$ We calibrate our productivity shock using these values, to arrive at a shock to labour augmenting technical change of $5.0 \%$ (Figure 15). Labour augmenting technical change is an exogenous variable in NiGEM. It is part of the production function and will directly increase or decrease capacity output. The shock is subsequently propagated through the supply side of the economy (for further details see the technical appendix). We assume that the 5 per cent fall in labour augmented technical change is realised in totality on impact and that the shock is permanent rather than transitory.

Assuming that productivity (modelled as labour-augmenting technology) declines by 5 per cent causes GDP to decline by a further 5.1 per cent relative to its long-run baseline. That is, GDP declines by 7.8 per cent rather than 2.7 per cent compared to its long- run baseline (Figure 16). This brings our estimate of the GDP impact of the WTO scenario into line with the Treasury's central projection of 7.5 per cent for a similar scenario. This is also in line with the upper end of the OECD (2016) estimates.

The productivity shock feeds into a decline in UK private sector investment (Figure 17), which is about $10 \%$ lower in the long run than the baseline of remaining in the EU. This compares to a much smaller long-run decline in private sector investment of about $2.7 \%$ relative to baseline in the central scenario without a productivity shock. As one would expect from first principles, the lower level of capital stock leads to a long-run decline in output per hour worked relative to the baseline (Figure 18) of about $7.7 \%$ in the case with the productivity shock, compared to only $2.7 \%$ in the central scenario without a productivity shock. This feeds into a larger long-run decline in real consumer wages of $7.0 \%$ relative to baseline with the productivity shock, compared to $4.6 \%$ without, again in line with first principles.

\section{Conclusions}

In this article, we focus on the modelling of long-run shocks to the UK economy after leaving the EU in NiGEM. We focus on a WTO scenario in which the UK has no free trade agreement with the EU. In

15 That is, a $1 \%$ decline in trade would lead to a $0.2 \%$ to $0.3 \%$ decline in productivity. 
our modelling, we restrict attention to key four shocks: reductions in export market share in EU member countries, an increase in tariffs, a reduction in inward FDI flows and the repatriation of the UK's projected net contributions to the EU budget. For each of these four shocks, we have presented the size of the shocks, how they are implemented, and the key mechanisms by which they work their way through the model.

The export market share channel is the main mechanism by which leaving the EU leads to declines in GDP and consumption relative to the long-run baseline. The export market share channel accounts for a decline in GDP of $2.1 \%$ relative to the long-run baseline, out of a total projected reduction in GDP relative to the long-run baseline of $2.7 \%{ }^{16}$

${ }^{16}$ Our results on reductions in GDP for scenarios assuming closer links to the EU after exiting, following Norwegian or Swiss models, lead to somewhat smaller reductions in GDP relative to the baseline, but remain clearly negative. See Ebell and Warren (2016) for details. 


\section{References}

Anderson, J. and van Wincoop, E. (2003), 'Gravity and gravitas: a solution to the border puzzle', American Economic Review, 93(1), pp. 170-92.

Baier, S., Bergstrand, J., Egger, P. and McLaughlin, P. (2008), 'Do economic integration agreements actually work? Issues in understanding the causes and consequences of the growth in regionalism', The World Economy, 31(4), pp. 461-97.

Bloom, N.,Lemos, R., Sadun, R., Scure, D., and van Reenan, J., (2014), 'The new empirical economics of management', Journal of the European Economic Association, vol 12

Bruno, R., Campos, N. and Estrin, S. (2016), 'Gravitating towards Europe: an econometric analysis of the FDI effects of EU membership', mimeo, London School of Economics.

Ebell, M. and J. Warren (2016), "The long-term economic impact of leaving the EU," National Institute Economic Review 236, 121-138.

Egger, P., Larch, M., Staub, K. and Winkelmann, R. (2011), 'The trade effects of endogenous preferential trade agreements', American Economic Journal: Economic Policy 3, pp. 113-43.

Head, K. and Mayer, T. (2014), 'Gravity equations: workhorse, toolkit, and cookbook', chapter 3 in Gopinath, G., Helpman, E. and Rogoff, K. (eds), Handbook of International Economics, vol. 4, Elsevier, pp. 131-95.

HM Treasury (2015), European Union Finances 2015: statement on the 2015 EU Budget and measures to counter fraud and financial mismanagement, Cm9167.

HM Treasury (2016), HM Treasury analysis: the long-term economic impact of EU membership and the alternatives, $\mathrm{Cm} 9250$.

Kirby, S., Carreras, O., Meaning, J., Piggott R., and Warren J., (2016), 'Prospects for the UK Economy' The National Institute Economic Review, No. 235, pp. F47-F76

Melitz, M., J., and Trefler, D., (2012), 'Gains from trade when firms matter', American Economic Association, Vol 26, No.2, pp91-118

Melitz, M., J., and Redding, S., (2014), 'Missing gains from trade', American Economic Review, Vol 104 no.5, pp317-321

OECD (2016), The economic consequences of Brexit: A taxing decision. Office for Budget Responsibility (2015),

Office for National Statistics (2016), Balance of payments Oct to Dec and annual for 2015.

Pain, N. and Young, G. (2004), 'The macroeconomic impact of UK withdrawal from the EU', Economic Modelling, 21, pp. 387-408.

Ramasamy, B. and Yeung, M. (2010), 'The determinants of foreign direct investment in services', The World Economy, pp. 573-596,

van der Marel, E. and Shepherd, B. (2013), 'Services trade, regulation and regional integration: evidence from sectoral data', The World Economy, pp. 1393-405.

Webb, D. and Keep, M. (2016), 'In brief: UK-EU economic relations', House of Commons Library Briefing Paper 06091. 


\section{Tables}

\section{Table 1: WTO scenario, assumptions}

\begin{tabular}{lc}
\hline Shock & Magnitude \\
\hline Reduction in UK export market share in EU & $50 \%$ \\
Increase in tariffs on UK trade with the EU & $5 \%$ \\
Reduction in inward FDI flows to the UK & $24 \%$ \\
EU budget savings, \% of GDP & $0.3 \%$ \\
\hline
\end{tabular}

Table 2a: WTO scenario, summary of results

\begin{tabular}{lrrrrrrr} 
& 2016 & 2017 & 2018 & 2019 & 2020 & 2025 & 2030 \\
\hline Percentage changes relative to base & & & & & & & \\
\hline GDP & -0.2 & -1.0 & -2.3 & -2.8 & -2.5 & -2.6 & -2.7 \\
Consumption & -0.1 & -1.2 & -1.7 & -2.1 & -2.4 & -3.2 & -4.0 \\
Investment (PSI) & -4.8 & -15.0 & -12.8 & -8.1 & -4.6 & -3.4 & -2.7 \\
Real consumer wages & -0.6 & -1.9 & -2.1 & -2.9 & -3.5 & -4.2 & -4.6 \\
$\quad$ Output per hour worked & -0.4 & -1.1 & -1.6 & -1.6 & -1.8 & -2.4 & -2.7 \\
\hline Changes in levels relative to base & & & & & & & \\
\hline Unemployment, \% & -0.2 & -0.1 & 0.7 & 1.2 & 0.8 & 0.3 & 0.1 \\
Inflation & 0.7 & 2.2 & 1.3 & 1.3 & 0.4 & 0.1 & 0.0 \\
Bank rate, \% & 0 & 0 & 0.25 & 0.50 & 0.00 & 0.00 & -0.25 \\
Long rate, \% & 0.5 & 1.0 & 0.1 & -0.1 & -0.1 & -0.1 & -0.2 \\
Effective direct tax rate, \% & 0.0 & 0.1 & 0.2 & 0.4 & 0.6 & 0.3 & 0.6 \\
\hline
\end{tabular}

Table 2b: WTO scenario, external sector

\begin{tabular}{lrrrrrrr} 
& 2016 & 2017 & 2018 & 2019 & 2020 & 2025 & 2030 \\
\hline Percentage changes relative to base & & & & & & & \\
\hline Exports & 0.5 & -6.1 & -17.5 & -23.1 & -23.3 & -21.8 & -20.7 \\
Imports & -1.4 & -11.6 & -18.6 & -21.1 & -21.2 & -20.9 & -20.7 \\
Trade & -0.5 & -9.0 & -18.1 & -22.0 & -22.2 & -21.3 & -20.7 \\
Effective exchange rate & -7.3 & -16.0 & -15.5 & -16.3 & -16.7 & -16.1 & -16.1 \\
$\quad$ Terms of trade & 0.7 & -0.5 & -0.5 & -1.8 & -2.5 & -3.8 & -4.0 \\
\hline Changes in levels relative to base & & & & & & & \\
\hline Trade balance, \% of GDP & 0.7 & 1.6 & 0.3 & -1.1 & -1.4 & -1.3 & -1.1 \\
Income balance, \% of GDP & 0.4 & 1.1 & 0.7 & 0.1 & 0.3 & 0.1 & 0.4 \\
$\quad$ Current acct balance, \% of GDP & 1.0 & 2.6 & 0.9 & -1.1 & -1.2 & -1.3 & -0.8 \\
\hline
\end{tabular}




\begin{tabular}{|c|c|c|c|c|}
\hline & OECD & HM Treasury & \multicolumn{2}{|c|}{ NIESR } \\
\hline & WTO/FTA & WTO & WTO & WTO + \\
\hline \multicolumn{5}{|c|}{ Modelling } \\
\hline Reduction in total trade & $-10 \%$ to $-20 \%$ & $-17 \%$ to $-24 \%$ & $-21 \%$ & $-22 \%$ \\
\hline Reduction in FDI & $-10 \%$ to $-45 \%$ & $-18 \%$ to $-26 \%$ & $-24 \%$ & $-24 \%$ \\
\hline EU budget savings, $\%$ of GDP & $0.3 \%$ to $0.4 \%$ & $0.4 \%$ & $0.3 \%$ & $0.3 \%$ \\
\hline \multicolumn{5}{|c|}{ Results } \\
\hline \multicolumn{5}{|l|}{ GDP, \% change from base } \\
\hline Central estimate & $-5.10 \%$ & $-7.5 \%$ & $-3.2 \%$ & $-7.8 \%$ \\
\hline Range & $-2.7 \%$ to $-7.7 \%$ & $-5.4 \%$ to $-9.5 \%$ & $-2.7 \%$ & $-7.8 \%$ \\
\hline Real consumer wages, $\%$ change from base & n.a. & n.a. & $-4.6 \%$ & $-7.0 \%$ \\
\hline Ratio of GDP to trade declines & $0.27-0.39$ & $0.32-0.40$ & 0.13 & 0.35 \\
\hline \multicolumn{5}{|c|}{ Channels } \\
\hline Reduced trade with EU & $\mathrm{x}$ & $\mathrm{x}$ & $x$ & $\mathrm{x}$ \\
\hline Productivity losses from reduction in trade & $x$ & $x$ & & $x$ \\
\hline Reduction in FDI & $x$ & $x$ & $x$ & $x$ \\
\hline Productivity losses from reduced FDI & $x$ & $x$ & & $x$ \\
\hline Change in migration & $x$ & & & \\
\hline Productivity gains from deregulation & $\mathrm{x}$ & & & \\
\hline Lower or zero contributions to the EU budget & $x$ & $x$ & $x$ & $x$ \\
\hline
\end{tabular}


Figures

Figure 1

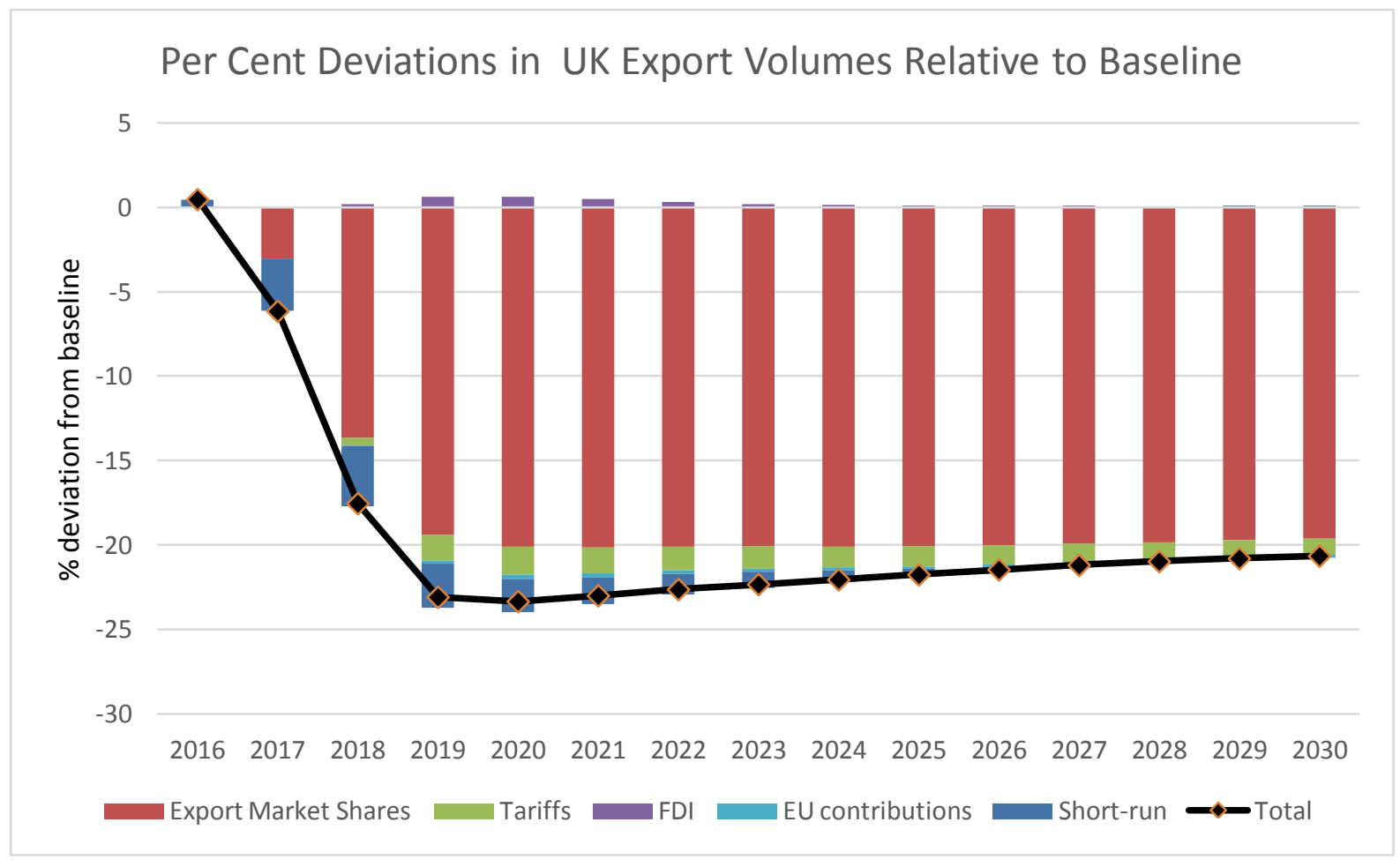

Figure 2

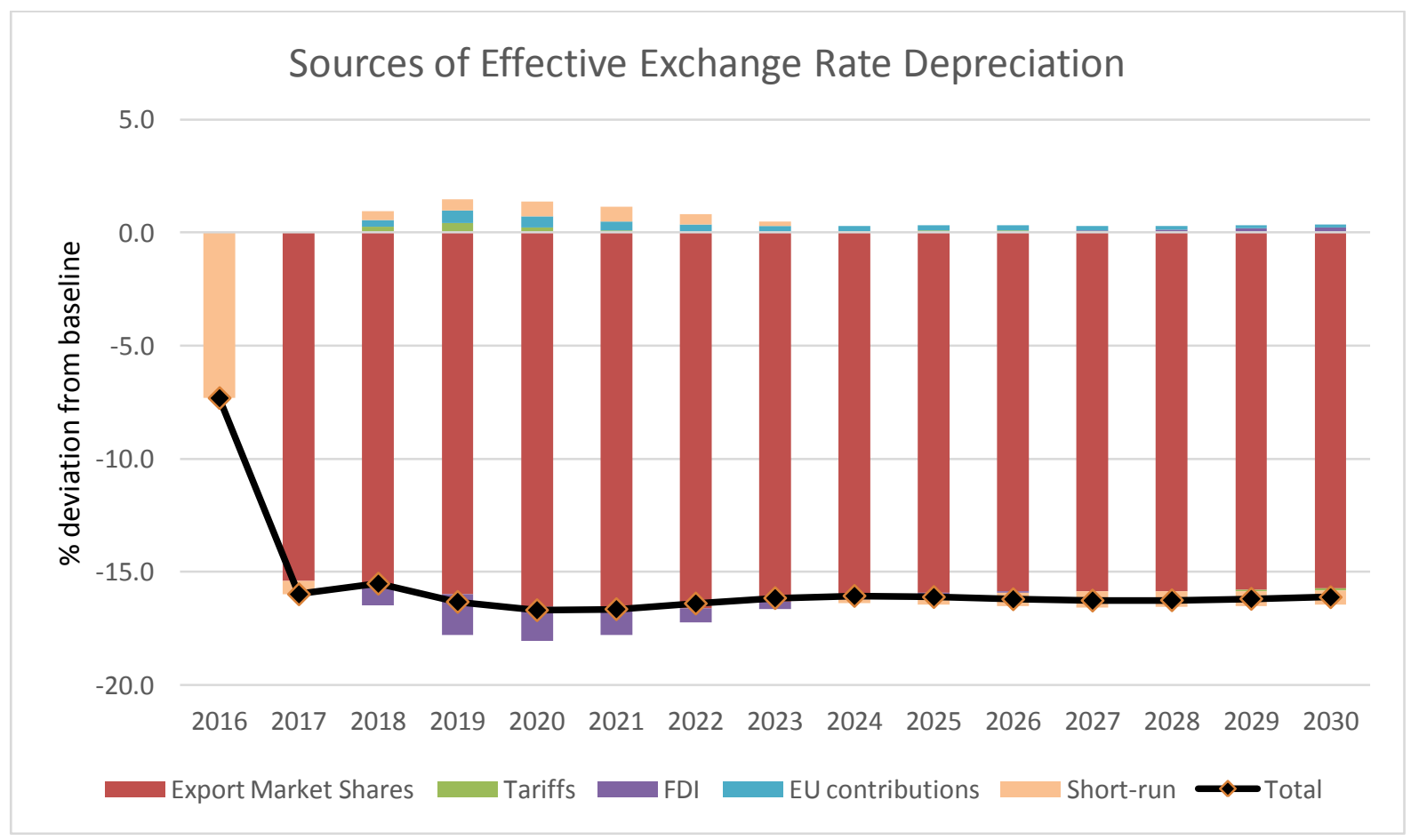




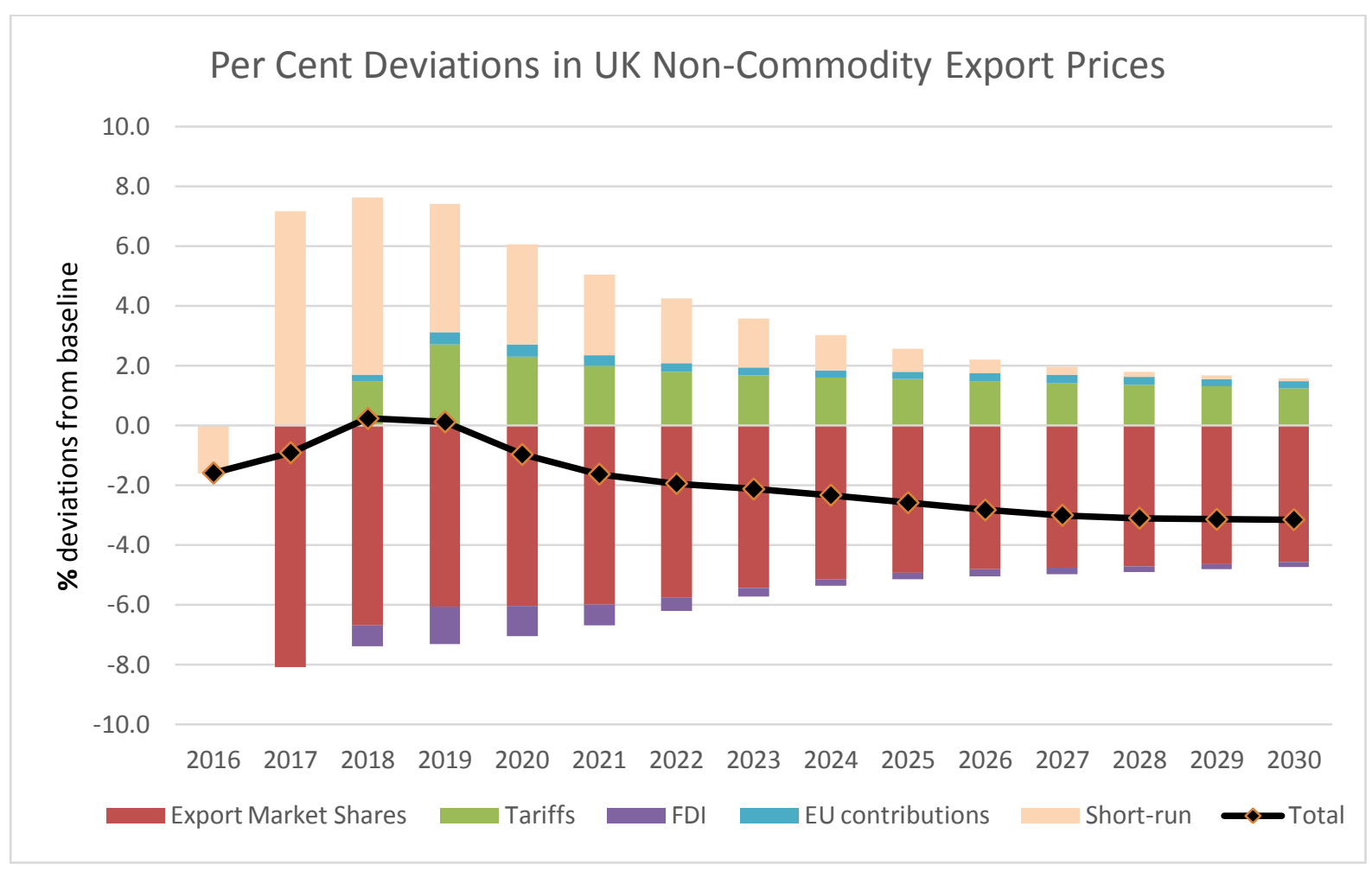

Figure 4

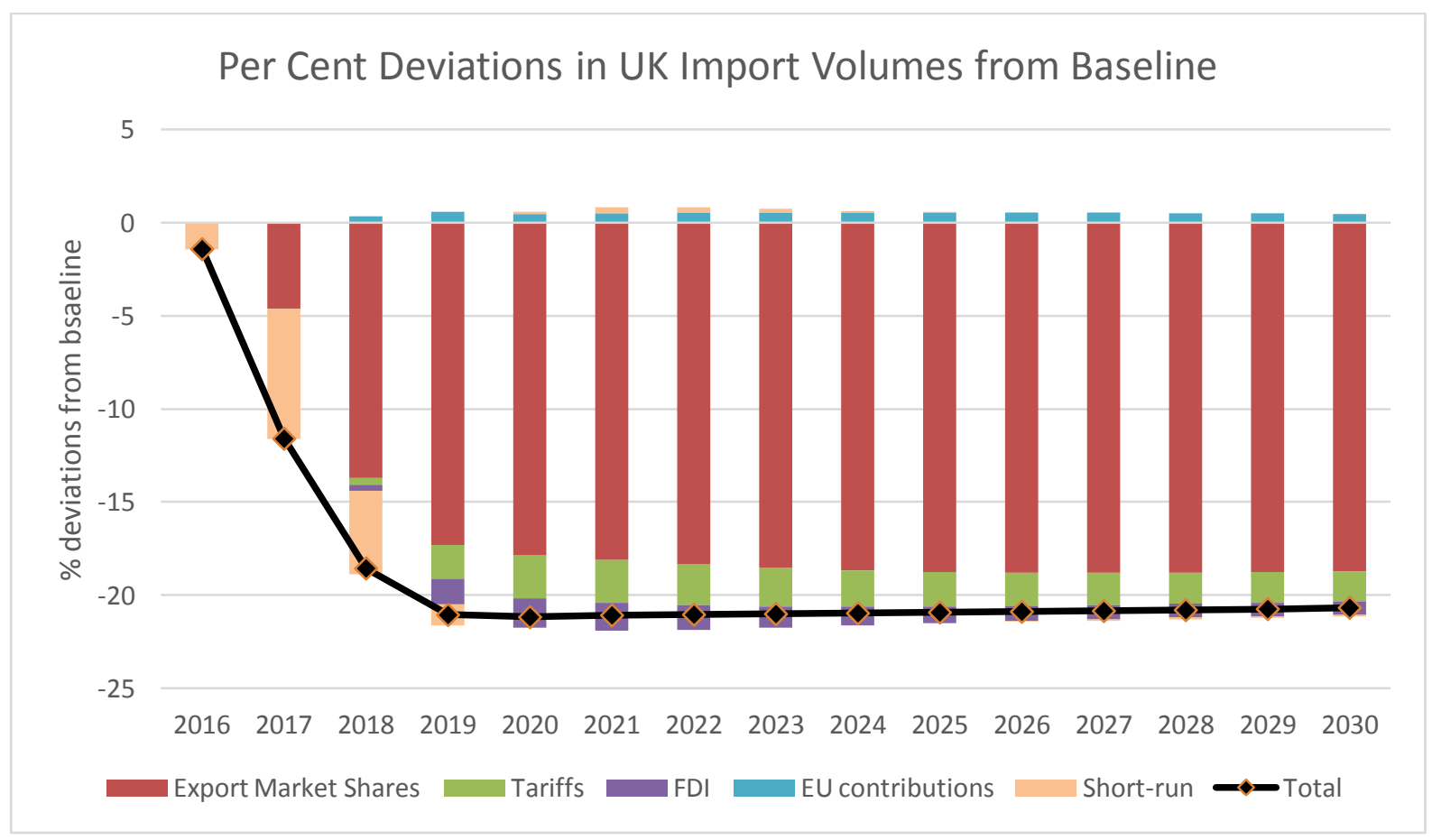




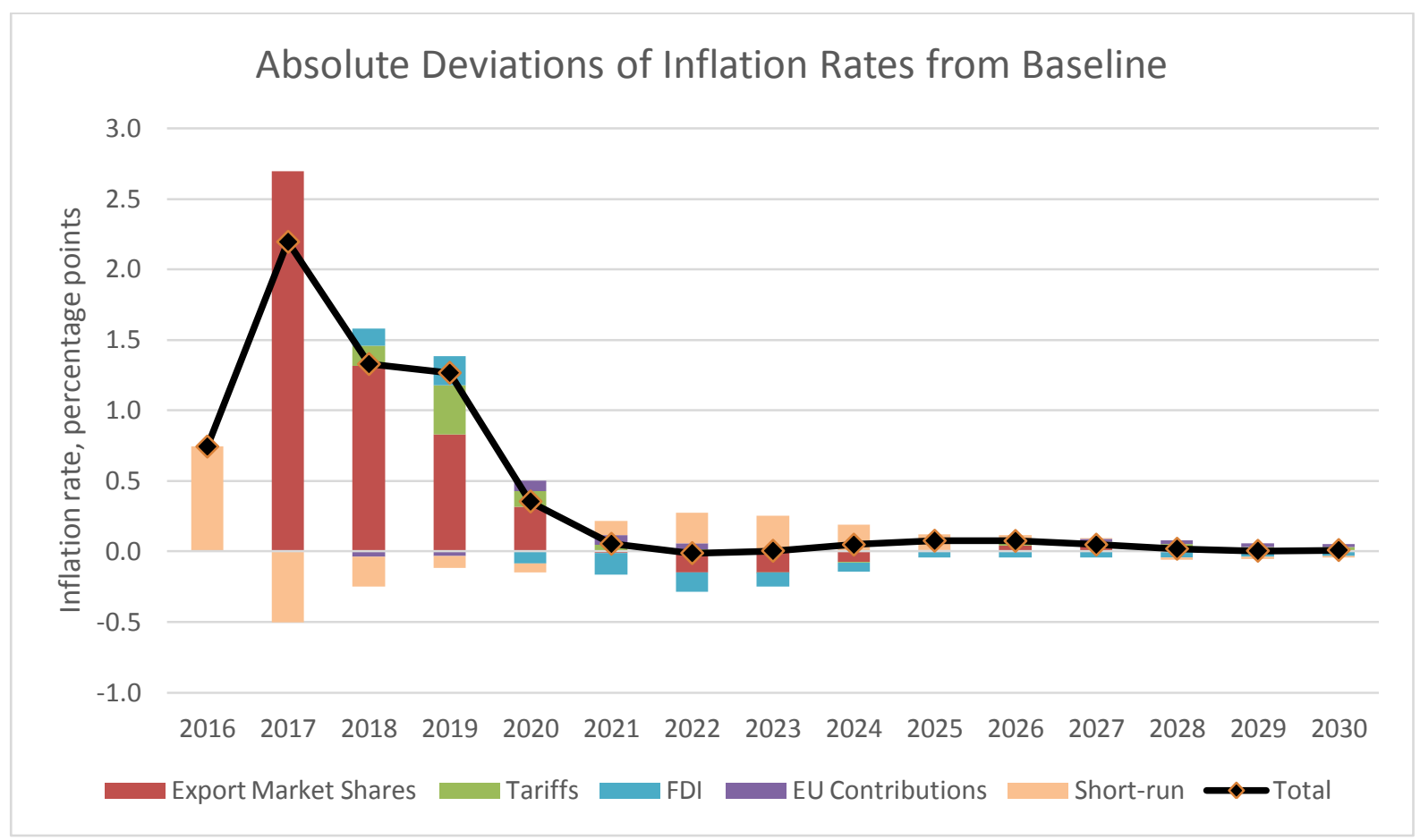

Figure 6

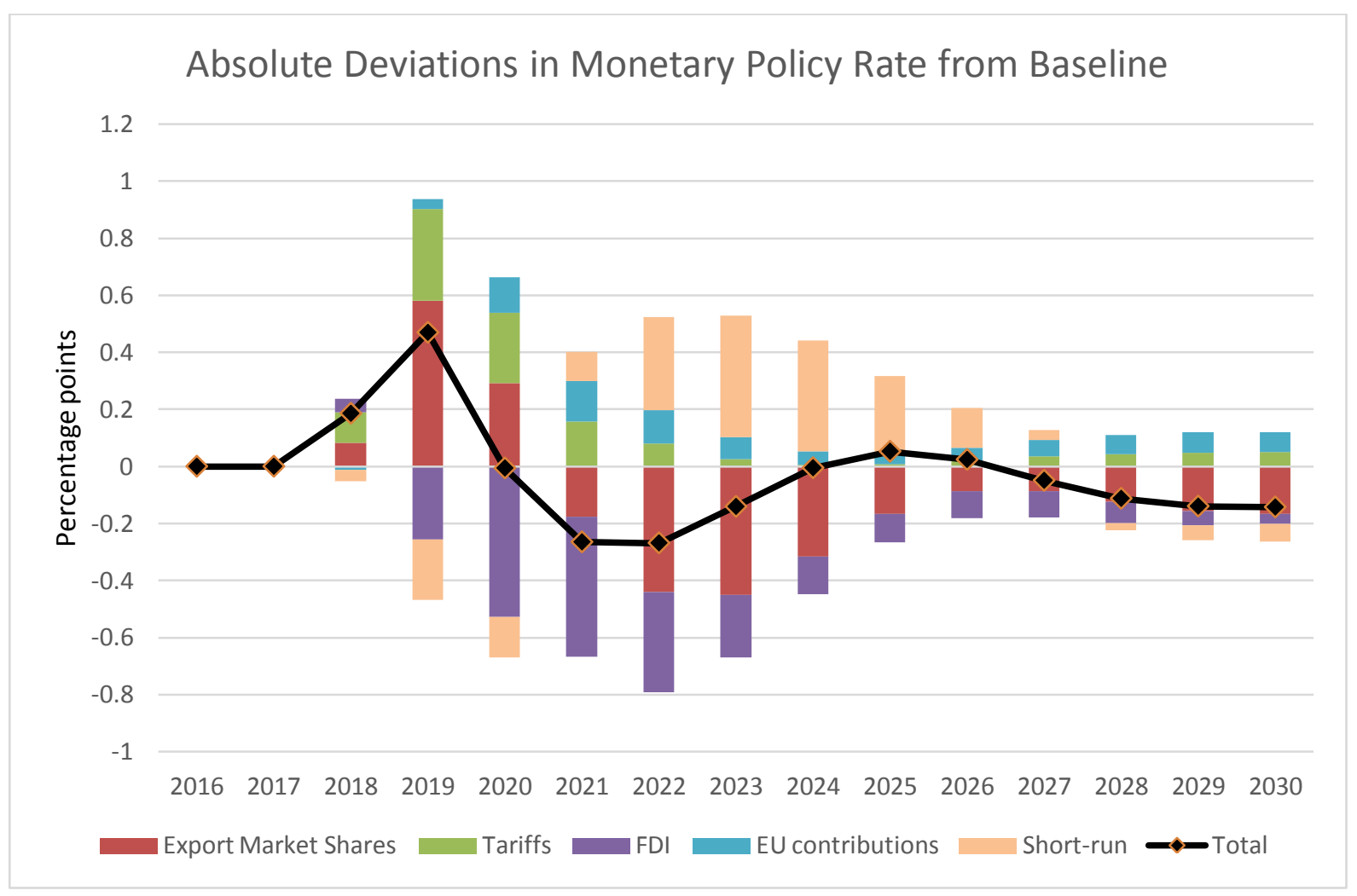




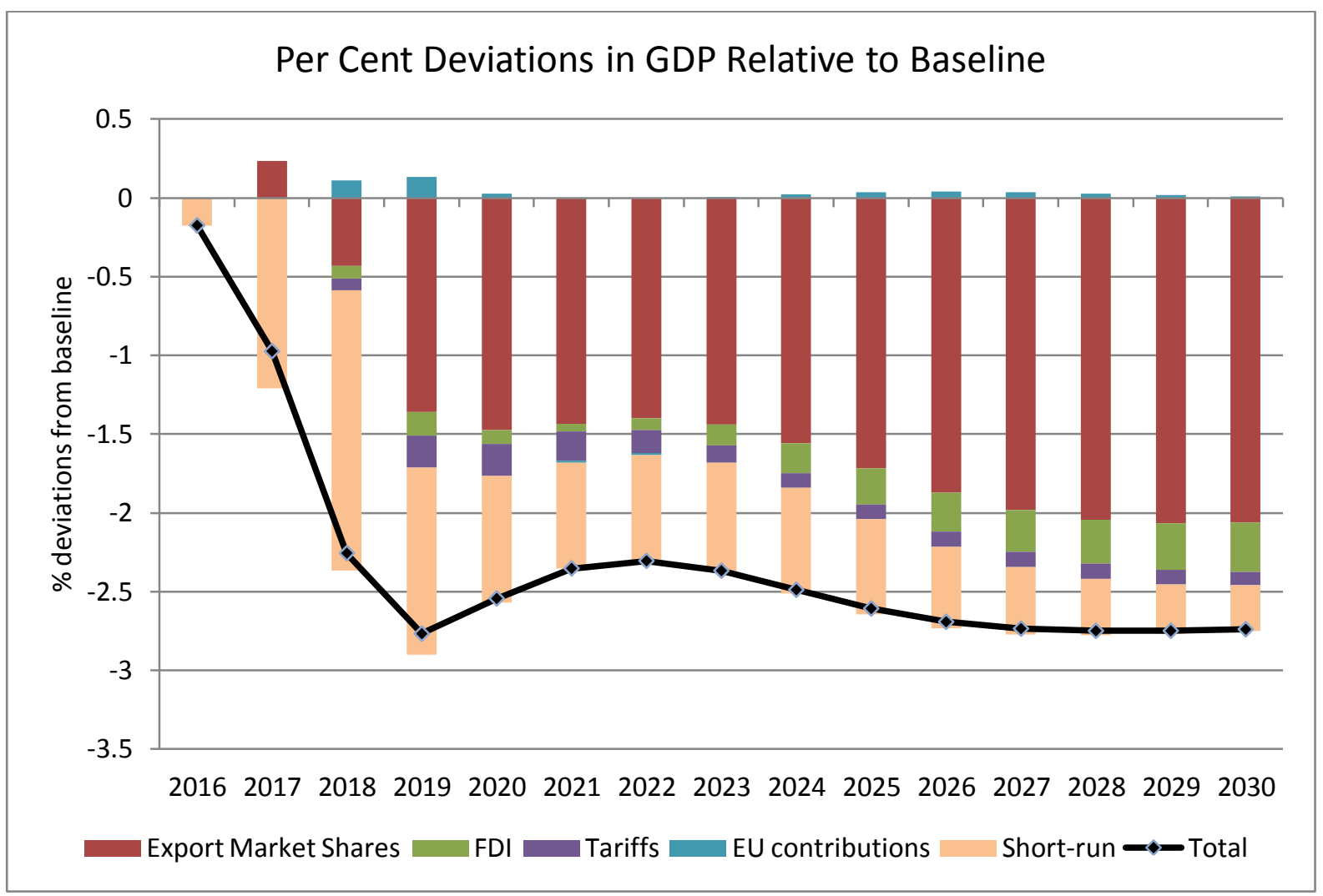

Figure 8

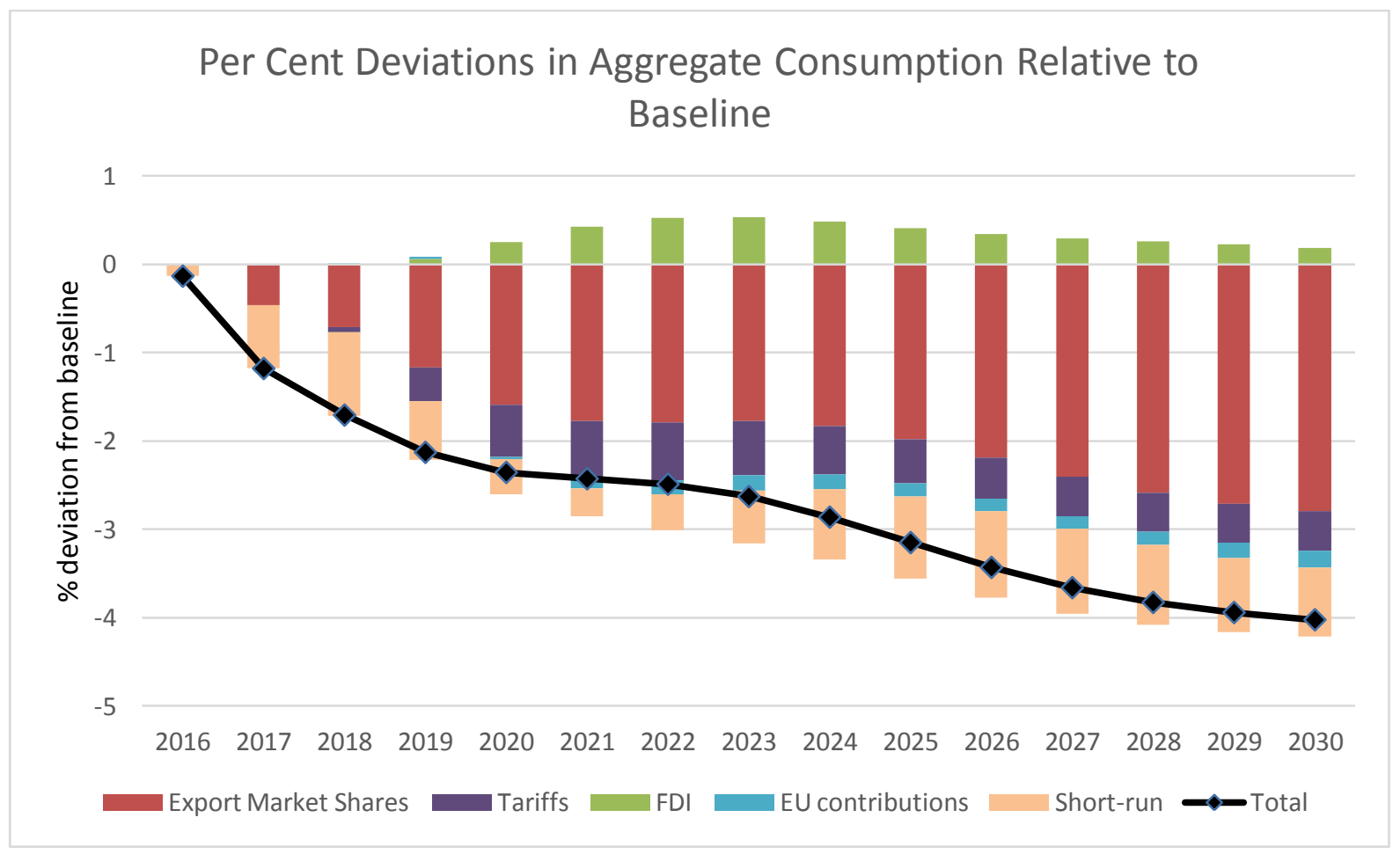




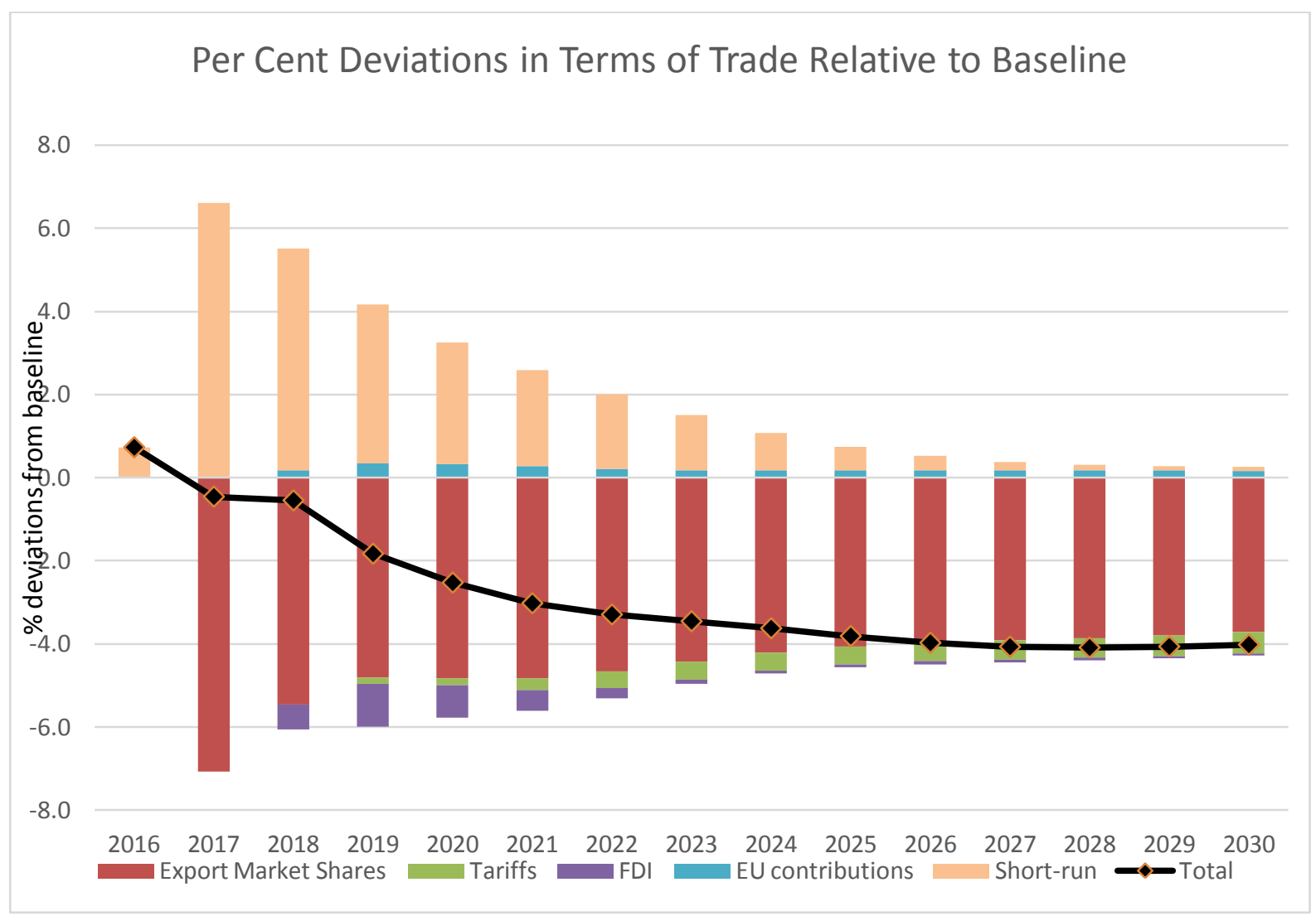

Figure 10

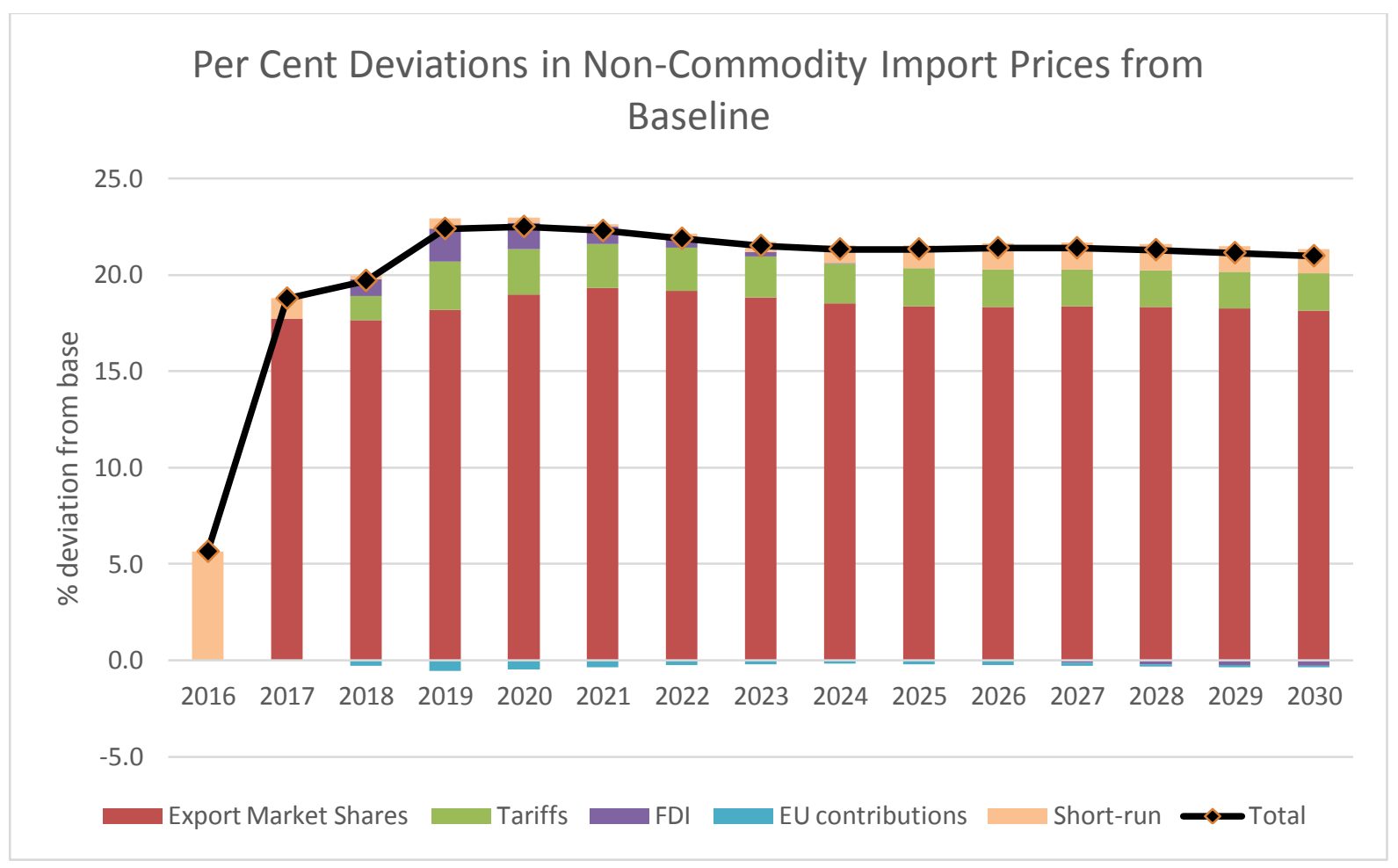




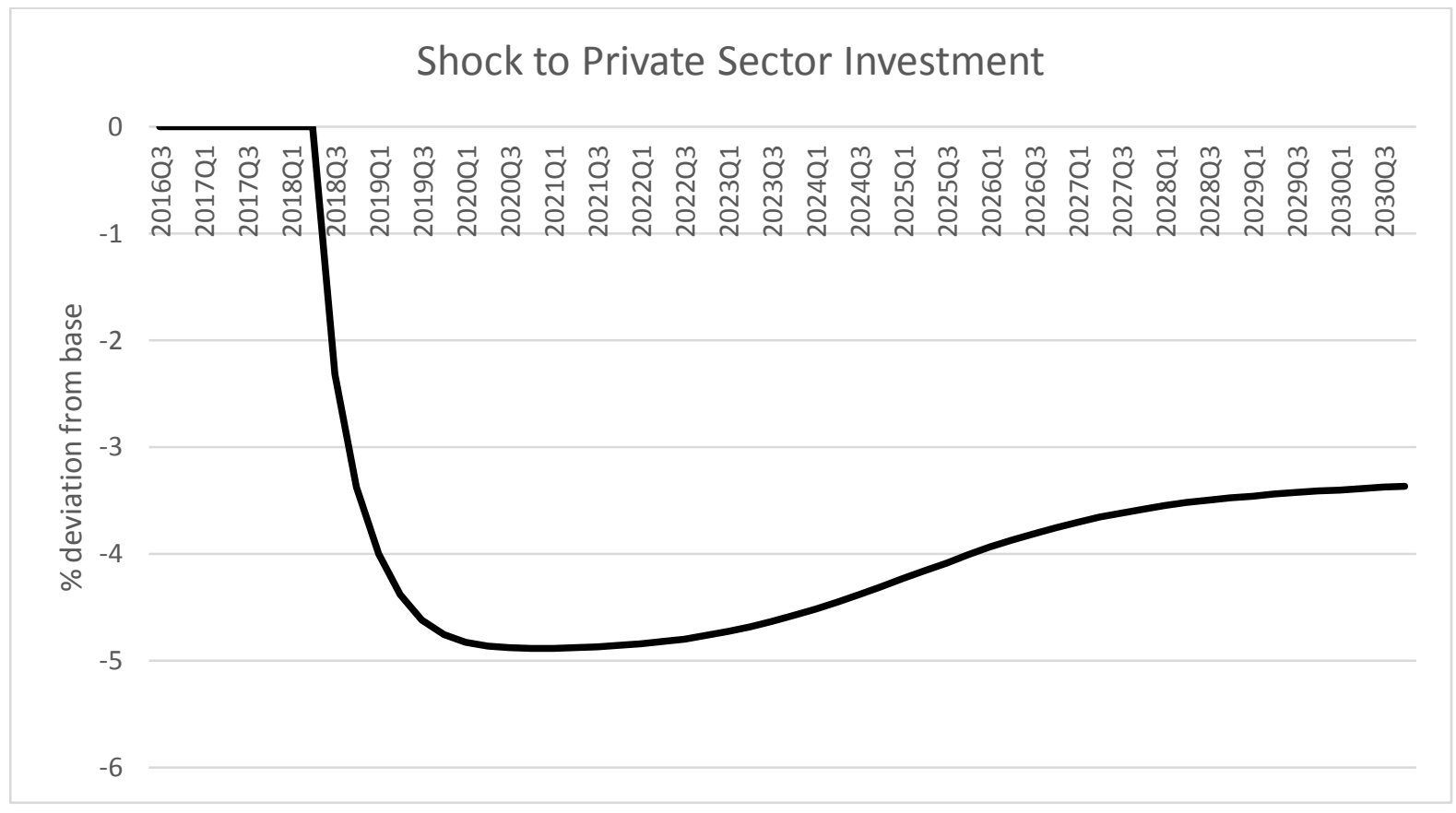

Figure 12

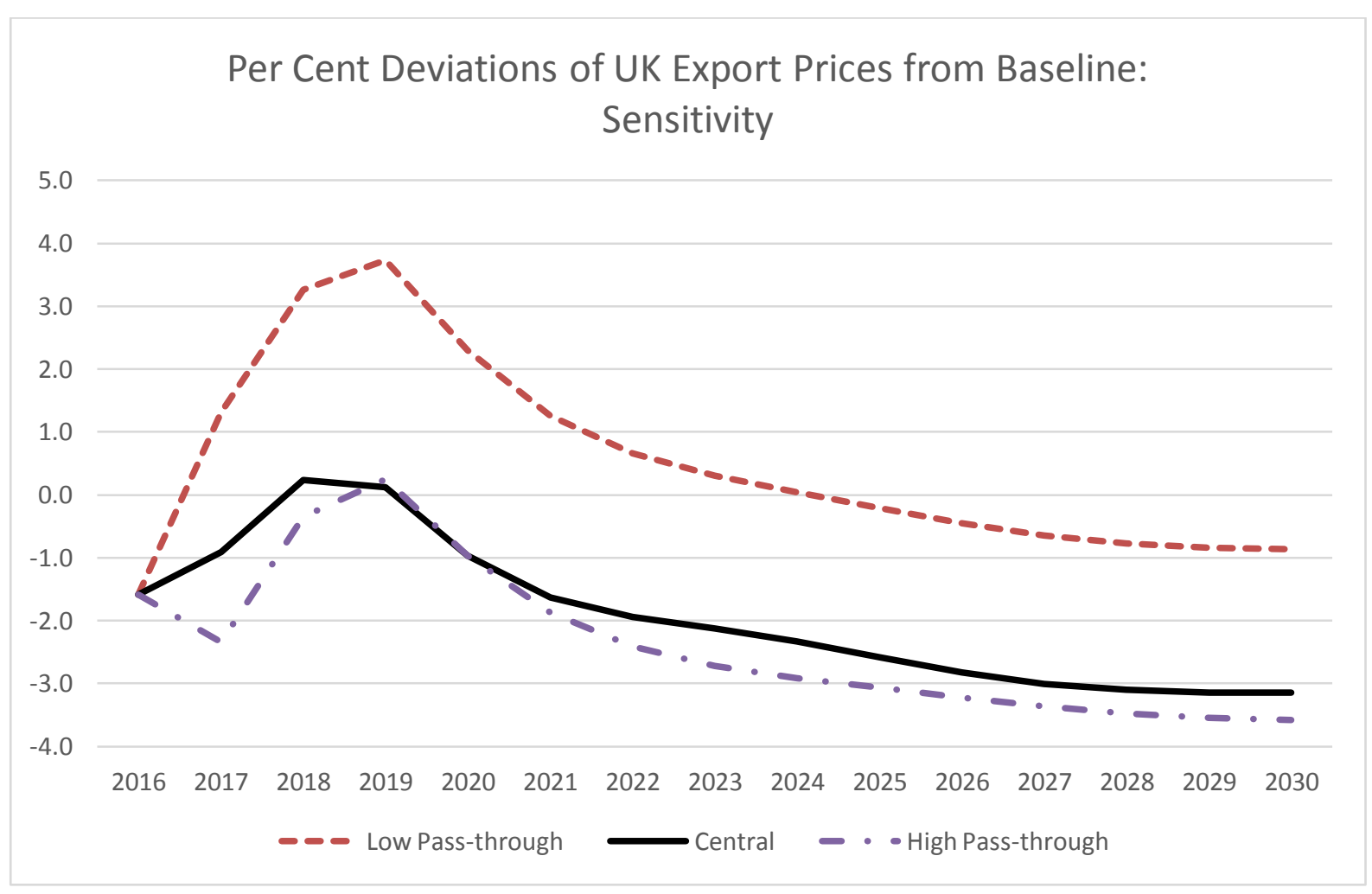




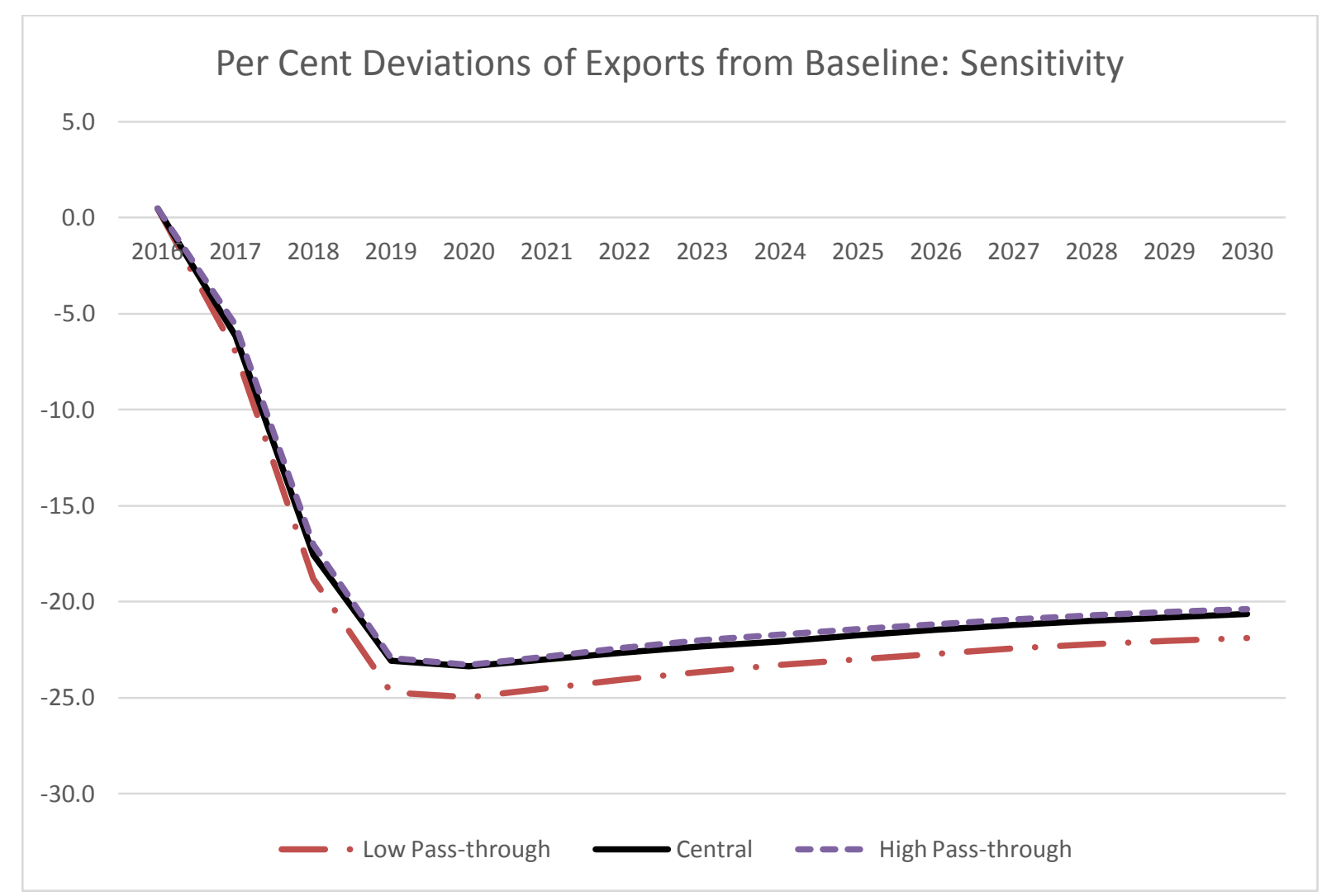

Figure 14

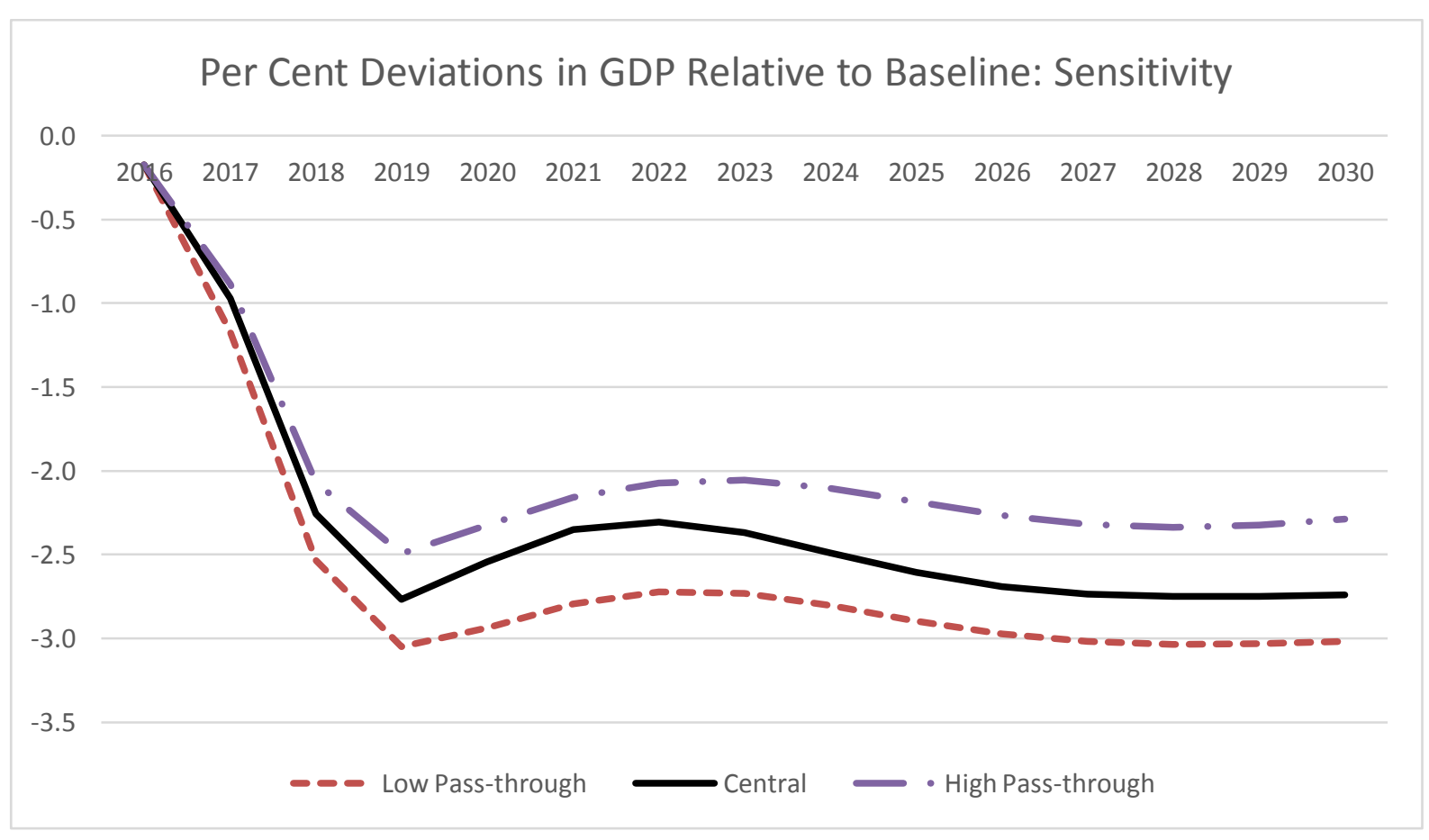




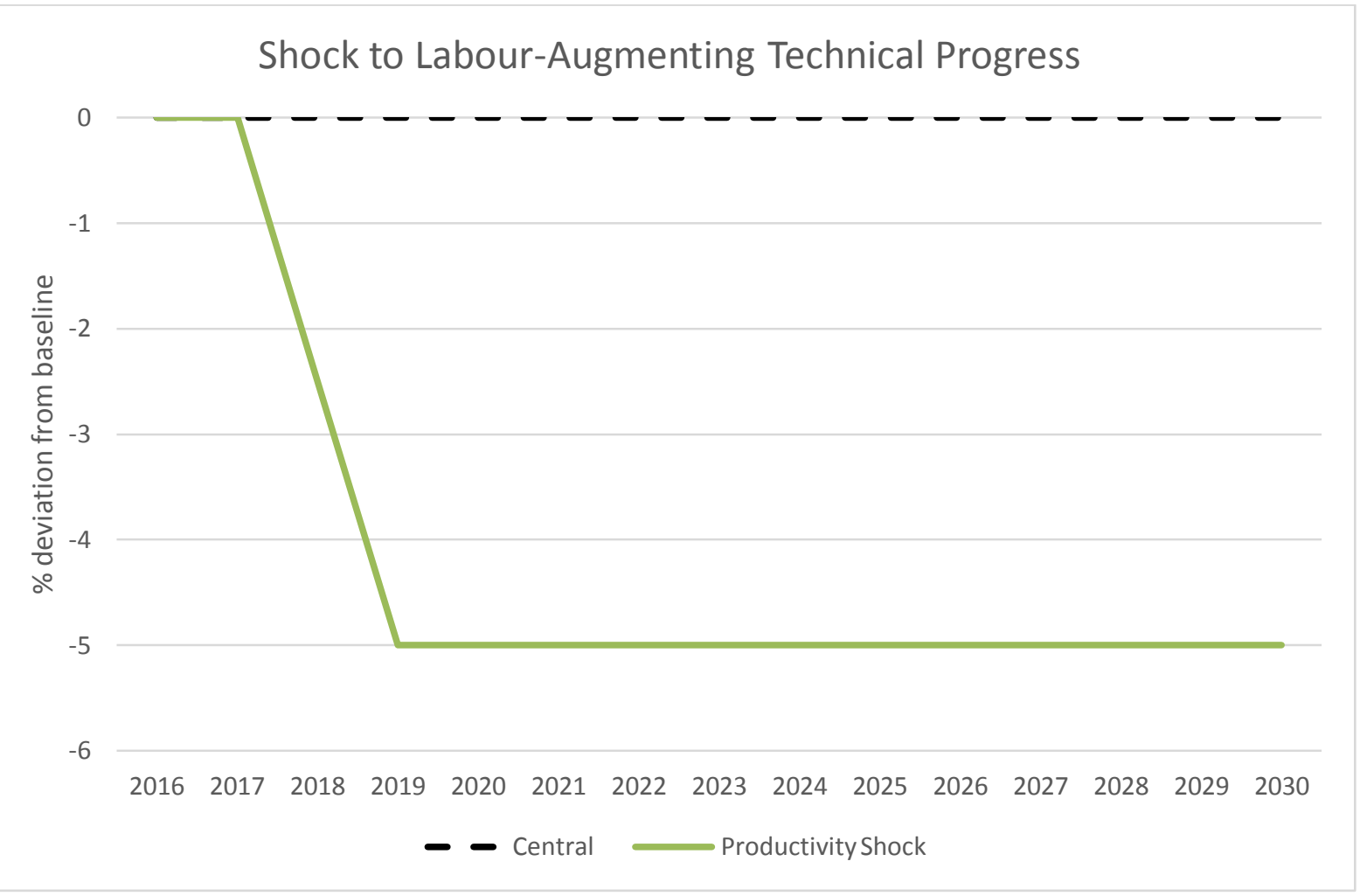

Figure 16

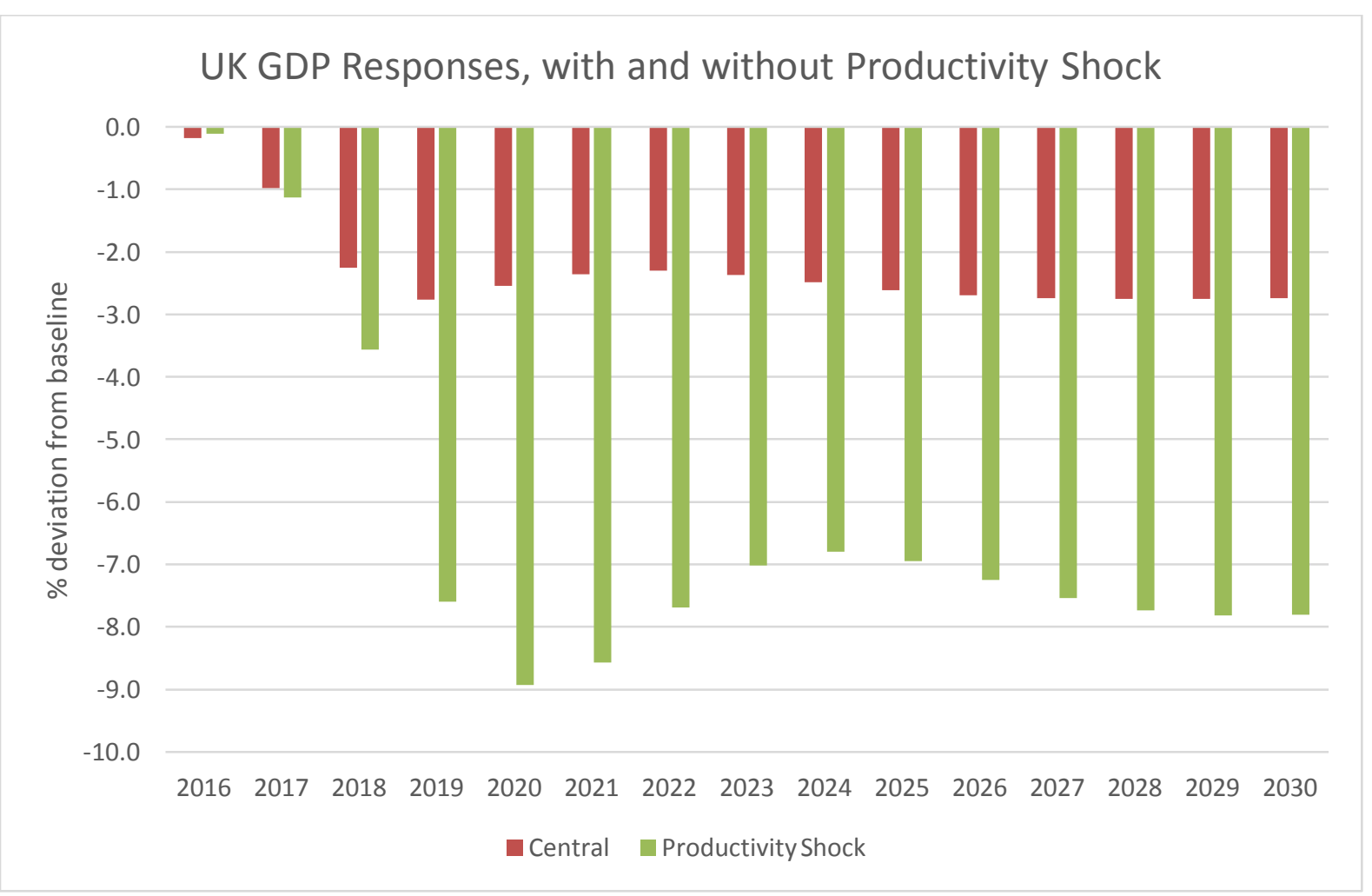




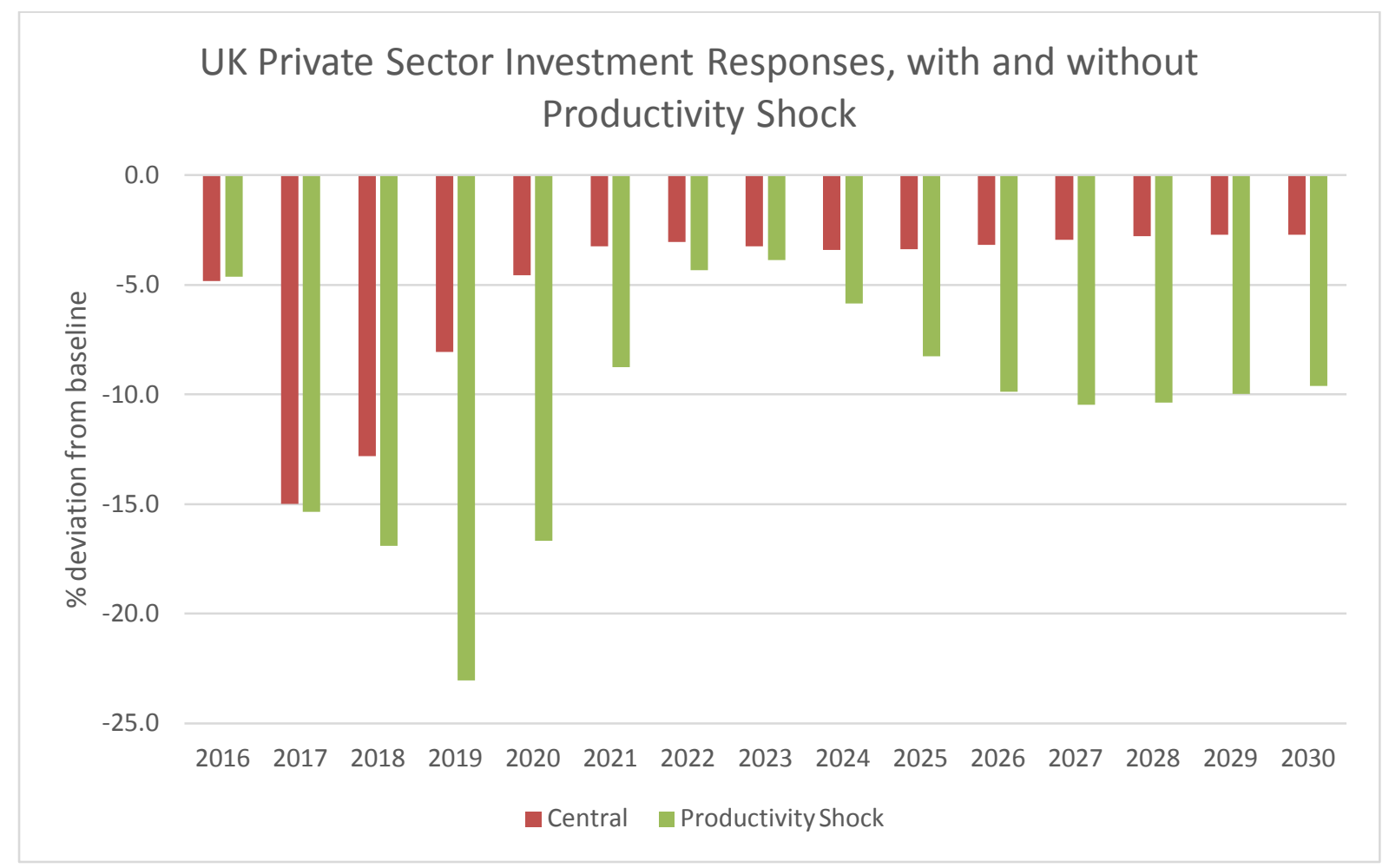

Figure 18

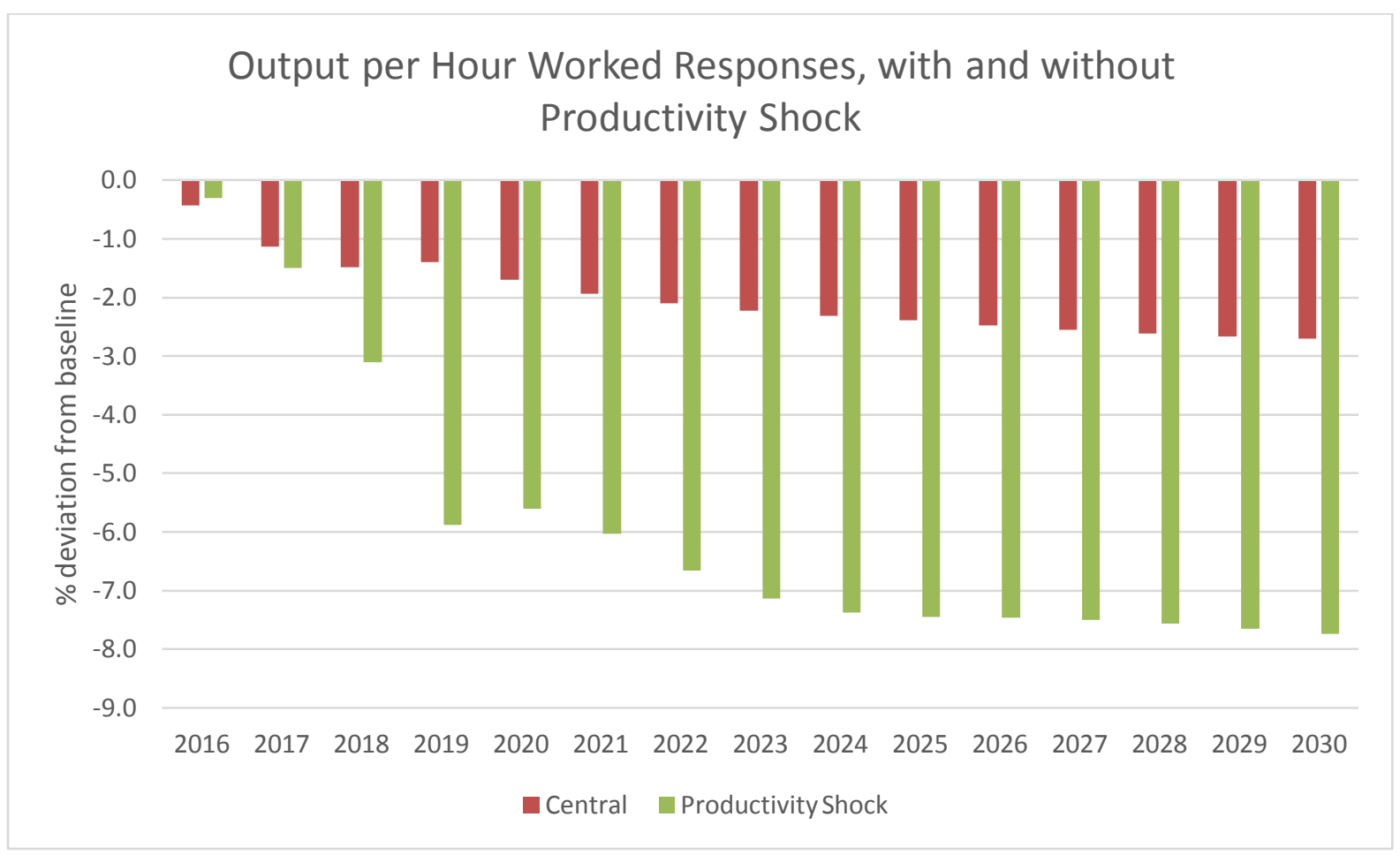


